\title{
Prostaglandin-induced programmed cell death in Trypanosoma brucei involves oxidative stress
}

\author{
K Figarella ${ }^{1}$, NL Uzcategui ${ }^{1}$, A Beck ${ }^{2}$, C Schoenfeld ${ }^{1}$, \\ BK Kubata ${ }^{3}, \mathrm{~F}$ Lang $^{4}$ and M Duszenko ${ }^{*, 1}$ \\ 1 Interfaculty Institute of Biochemistry, University of Tuebingen, Germany; \\ 2 Department of Internal Medicine IV, University of Tuebingen, Germany; \\ 3 US Army Medical Research Unit-Kenya, Nairobi, Kenya; \\ 4 Institute of Physiology, University of Tuebingen, Germany \\ * Corresponding author: M Duszenko, Interfakultäres Institut für Biochemie, \\ Hoppe-Seyler-Str. 4, 72076 Tübingen, Germany. Tel: + 497071297 3343; \\ Fax: + 49707129 5009; E-mail: michael.duszenko@uni-tuebingen.de
}

Received 09.9.05; revised 12.12.05; accepted 15.12.05; published online 03.2.06 Edited by P Golstein

\begin{abstract}
Recently, we reported the induction of a programmed cell death (PCD) in bloodstream forms of Trypanosoma brucei by prostaglandin $D_{2}\left(P G D_{2}\right)$. As this prostanoid is readily metabolized in the presence of albumin, we were prompted to investigate if $P G D_{2}$ metabolites rather than $P G D_{2}$ itself are responsible for the observed $P C D$. In fact, $J$ series metabolites, especially $P \mathrm{PJ}_{2}$ and $\Delta^{12} P \mathrm{PJ}_{2}$, were able to induce PCD more efficiently than $\mathrm{PGD}_{2}$. However, the stable $P G D_{2}$ analog 17 phenyl-trinor- $P G D_{2}$ led to the same phenotype as the natural $P G D_{2}$, indicating that the latter induces $P C D$ as well. Interestingly, the intracellular reactive oxygen species (ROS) level increased significantly under $\mathrm{J}$ series metabolites treatment and, incubation with $\mathrm{N}$-acetyl-L-cysteine or glutathione reduced ROS production and cell death significantly. We conclude that $P G J_{2}$ and $\Delta^{12} P G J_{2}$ formation within the serum represents a mechanism to amplify $P G D_{2}$-induced $P C D$ in trypanosomes via ROS production.

Cell Death and Differentiation (2006) 13, 1802-1814. doi:10.1038/sj.cdd.4401862; published online 3 February 2006
\end{abstract}

Keywords: apoptosis; prostaglandin metabolism; programmed cell death; reactive oxygen species; Trypanosoma brucei

\begin{abstract}
Abbreviations: DCFH-DA, 2', 2' $^{\prime}$-dichlorodihydrofluorescein diacetate; dUTP, deoxyuridinetriphosphate; EIC, extracted ion chromatogram; $\Psi \mathrm{m}$, mitochondrial membrane potential; FACS, fluorescence-activated cell sorting; LC-ESI/MS, liquid chromatography electrospray ionization mass spectrometry; NAC, $\mathrm{N}$-acetyl-L-cysteine; PCD, programmed cell death; PG, prostaglandin; ROS, reactive oxygen species; TEM, transmission electron microscopy; TUNEL, terminal deoxynucleotidyl transferase-mediated dUTP nick end labeling
\end{abstract}

\section{Introduction}

The protozoan hemoflagellate Trypanosoma brucei is the causative agent of sleeping sickness in humans and of nagana in domestic animals. This unicellular eucaryote has a complex life cycle involving several morphologically and biochemically distinguishable stages during its development in the mammalian host (bloodstream form) and the tsetse fly vector (procyclic form). ${ }^{1,2}$ Trypanosomes evade the host immune system by a combination of antigenic variation ${ }^{3}$ and immune suppression. ${ }^{4,5}$ The appearance of parasitic waves in blood during the course of infection is attributed to the action of specific antibodies. However, this behavior was also observed in vitro if culture medium was regularly replaced by fresh medium. ${ }^{6}$ Thus, this parasitemia is controlled by the immune system of the host and is also regulated by the parasite itself. ${ }^{7}$

Untreated trypanosome infections are lethal. Patients with advanced sleeping sickness show an elevated prostaglandin (PG) level in their cerebrospinal fluid. ${ }^{8}$ PGs are produced by many cell types in response to a variety of stimuli. ${ }^{9,10}$ They are synthesized from arachidonic acid via an unstable endoperoxide intermediate by a cyclooxygenase and are eventually converted by specific synthases to one of several related products, such as $\mathrm{PGD}_{2}, \mathrm{PGE}_{2}$ and $\mathrm{PGF}_{2 \alpha}$. $\mathrm{PGs}$ have been shown to play a prominent role in inflammatory processes, regulation of vascular tone, infertility, pain, fever, sleep, apoptosis and others. ${ }^{11-16}$ The PG production is not restricted to mammals but has also been described in parasites such as cestodes, trematodes, nematodes and protozoa. ${ }^{17-20}$ In Schistosoma mansoni, the PG production has been associated with the transformation of cercaria into schistosomules, ${ }^{21}$ whereas in Amoeba proteus, its synthesis plays a role during phagocytosis, eliciting vacuole formation..$^{22}$ In the bloodstream form of $T$. brucei, an apoptosis-like programmed cell death (PCD) is induced by prostaglandin $\mathrm{D}_{2}\left(\mathrm{PGD}_{2}\right){ }^{23} \mathrm{PGD}_{2}$ is the major prostanoid produced and secreted by the stumpy bloodstream form of $T$. brucei, ${ }^{24}$ which was shown to be more sensitive to this compound than the slender bloodstream form. ${ }^{23}$ In this sense, the physiological function of $\mathrm{PGD}_{2}$ in trypanosomes can be related to the population density regulation by $P C D$ induction. However, it has already been shown that $\mathrm{PGD}_{2}$ undergoes dehydration in vivo and in vitro to additional, biologically active PGs of the $J$ series. ${ }^{25,26}$ Metabolites of the $\mathrm{J}$ series have their own unique spectrum of biological activities, including inhibition of cell cycle progression, suppression of viral replication, induction of heat-shock proteins, stimulation of osteogenesis and induction of apoptosis in different cell types. ${ }^{26-28}$ In this study, we analyzed the $\mathrm{PGD}_{2}$ metabolism under in vitro conditions and evaluated the effect of the produced metabolites on the bloodstream forms of $T$. brucei.

\section{Results}

Separation and identification of $\mathrm{PGD}_{2}$ metabolites in cultures

$\mathrm{PGD}_{2}$ is known to be spontaneously converted in blood and albumin-containing media to different metabolites, especially to the $J$ derivatives (Figure 1). ${ }^{25,26,29,30}$ In order to identify the respective metabolites produced under our experimental 
conditions, PGs were analyzed by liquid chromatography electrospray ionization mass spectrometry (LC-ESI/MS) in the negative-ion mode. $\mathrm{PGD}_{2}$ was metabolized to derivatives of the $J$ series $P G J_{2}, \Delta^{12} P G J_{2}$ and 15 deoxy- $P G J_{2}$ and derivatives of the $D$ series 15 keto- $P G D_{2}$ and 15 deoxy$\mathrm{PGD}_{2}$, as detected by their comigration with authentic and commercially available standards and by their ionic masses $(\mathrm{m} / \mathrm{z})$. Figure $2 \mathrm{a}$ shows the extracted ion chromatograms (EICs) of the single charged molecular ion $\mathrm{m} / \mathrm{z} 351.1$, [M-H] ${ }^{-}$ of the PGs. $\mathrm{PGD}_{2}$ could be detected by the formation of an intense peak eluting after $15.8 \mathrm{~min}$ in the $0 \mathrm{~h}$ sample, which strongly decreased after $20 \mathrm{~h}$ and was practically absent after $40 \mathrm{~h}$. Furthermore, the formation of $15 \mathrm{k}-\mathrm{PGD}_{2}$ could be observed by the detection of an additional peak in the $\mathrm{m} / \mathrm{z}$ 351.1 ion trace (14.2 $\mathrm{min}$ ) after 20 and $40 \mathrm{~h}$ (Figure $2 \mathrm{a}$ ). $P \mathrm{FJ}_{2}$, $\Delta^{12} \mathrm{PGJ}_{2}$ and $15 \mathrm{~d}-\mathrm{PGD}_{2}$ were detected by EIC of the single charged molecular ion $\mathrm{m} / \mathrm{z}$ 333.0, $[\mathrm{M}-\mathrm{H}]^{-}$(Figure $2 \mathrm{~b}$ ). The formation of $P G J_{2}$ and $15 \mathrm{~d}-\mathrm{PGD}_{2}$ was detected after $20 \mathrm{~h}$ incubation, which further increased after $40 \mathrm{~h}$ incubation. In addition, the formation of $\Delta^{12} \mathrm{PGJ}_{2}(16.9 \mathrm{~min})$ was observed only after $40 \mathrm{~h}$ incubation (Figure $2 \mathrm{~b}$ ). Finally, the $\mathrm{PGD}_{2}$ metabolite $15 \mathrm{~d}-\mathrm{PGJ}_{2}$ was detected as a peak eluting after $24 \mathrm{~min}$ in both the 20 and $40 \mathrm{~h}$ samples, as monitored by the EIC of the single charged molecular ion $\mathrm{m} / \mathrm{z} 315.1$ (Figure $2 \mathrm{c}$ ).

\section{Inhibition of cellular proliferation and induction of morphological changes by PGs of the $J_{2}$ series}

Following identification of $\mathrm{PGD}_{2}$ metabolites in culture media, we investigated their effects on cell growth of $T$. brucei. In addition, we used a stable $\mathrm{PGD}_{2}$ analog, 17phenyl-trinorprostaglandin $D_{2}$ (17phenyl- $P G D_{2}$ ), in order to explore if $\mathrm{PGD}_{2}$ itself is able to induce PCD. ${ }^{23}$ Using a $\left[{ }^{3} \mathrm{H}\right]$ thymidine incorporation assay, we found that $P G$ of the $J$ series, $P G J_{2}$ and $\Delta^{12} P \mathrm{GJ}_{2}$, strongly reduced cellular proliferation of $T$. brucei at concentrations significantly lower than those required for $\mathrm{PGD}_{2}(5 \mu \mathrm{M})$. $15 \mathrm{~d}-\mathrm{PG} \mathrm{J}_{2}$ showed similar effects as $\mathrm{PGD}_{2}$ in the inhibition of proliferation, whereas metabolites of the $D$ series, $15 \mathrm{k}-P \mathrm{CD}_{2}$ and $15 \mathrm{~d}-\mathrm{PGD}_{2}$, remained ineffective (Figure 3). The $\mathrm{IC}_{50}$ for each metabolite was determined after $24 \mathrm{~h}$ incubation of trypanosomes in culture media. As shown in Table 1, metabolites of the $D$ series were cytotoxic only at concentrations higher than $30 \mu \mathrm{M}$, suggesting that they do not play an important role in the $\mathrm{PGD}_{2}$-induced cell death. In contrast, $\mathrm{J}$ series metabolites have similar or lower $\mathrm{IC}_{50}$ than that for $\mathrm{PGD}_{2}$ (Table 1). In addition, 17phenyl-PGD 2 inhibited proliferation with an $\mathrm{IC}_{50}$ of $7.7 \mu \mathrm{M}$ (i.e. at a concentration twofold higher than that for $P G D_{2}$ ), demonstrating that $P G D_{2}$ itself is able to inhibit cellular growth. On the other hand, the results suggest that part of the $\mathrm{PGD}_{2}$ effects depend on the formation of $\mathrm{J}$ series metabolites.

Electron microscopic studies of the ultrastructure of $\mathrm{J}$ series metabolites-treated cells showed that these PGs induced typical morphological changes of PCD. After an incubation time of $20 \mathrm{~h}$, control cells show nuclei with a prominent central nucleolus and equally distributed chromatin, a not dilated mitochondrion and characteristic organelles (Figure $4 a-c)$. In contrast, most of the treated cells displayed a fragmented nucleus with condensed chromatin (Figure $4 d-g$ ), a swollen mitochondrion (Figure $4 \mathrm{k}, \mathrm{m}$ and $\mathrm{n}$ ) and an increase of

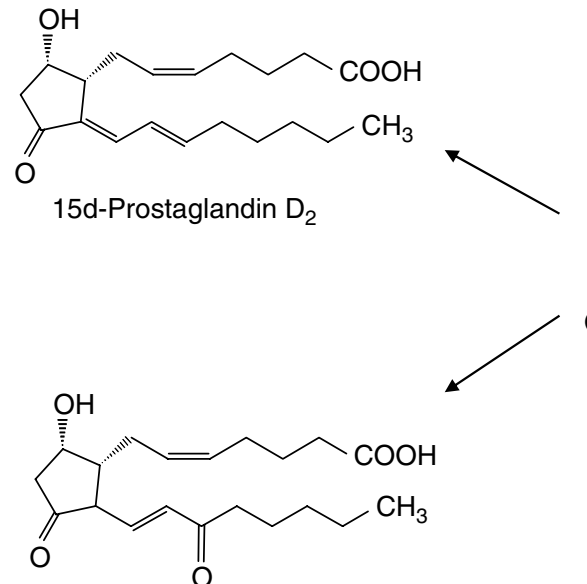

15keto-Prostaglandin $D_{2}$<smiles>O=C(O)CCC/C=C/C[C@H]1C(=O)C[C@H](O)C1/C=C/[C@H](O)CCc1ccccc1</smiles>

17-phenyl trinor Prostaglandin $\mathrm{D}_{2}$<smiles>CCCCC[C@H](O)/C=C/[C@H]1C(=O)C[C@@H](O)[C@@H]1C/C=C/CCCCC(=O)O</smiles><smiles>CCCCCC/C=C/C[C@H](O)/C=C/C1C(=O)C=C[C@@H]1/C=C/CCCC(=O)O</smiles>

Prostaglandin $\mathrm{J}_{2}$

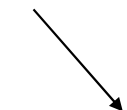<smiles>CCCCCC[C@H](O)C/C=C1/C(=O)C=C[C@@H]1C/C=C/CCCC(=O)O</smiles>

$\Delta^{12}$-Prostaglandin $\mathrm{J}_{2}$<smiles>CCCCC/C=C/C=C1/C(=O)C=C[C@@H]1C/C=C/CCCC(=O)O</smiles>

15d-Prostaglandin $\mathrm{J}_{2}$

Figure 1 Structures of the more important $P G D_{2}$ metabolite. The inset at the left bottom shows the structure of the $P G D_{2}$ analog, 17 phenyl-PGD 

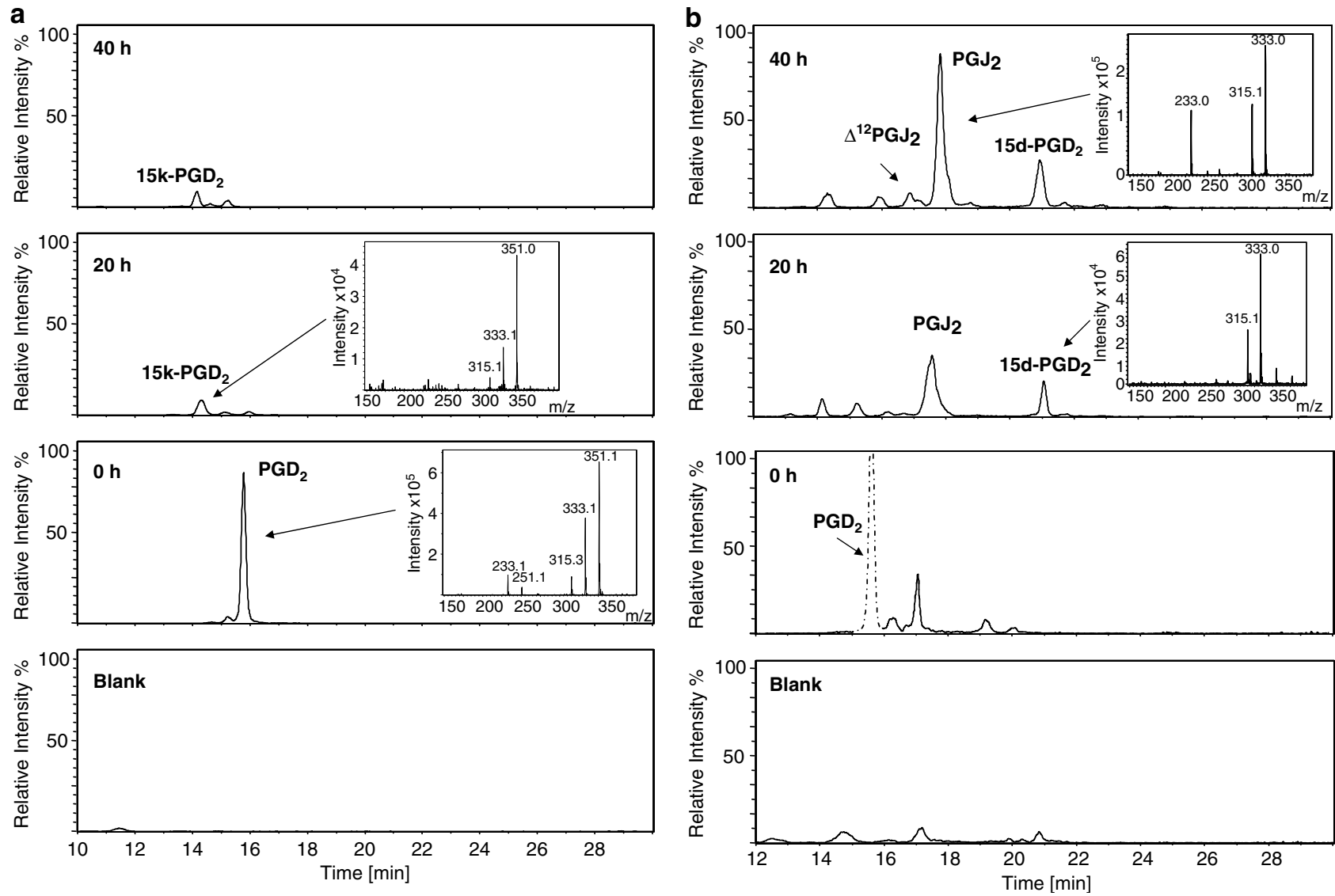

Figure 2 LC-ESI/MS analysis of $\mathrm{PGD}_{2}$ metabolites. $\mathrm{PGD}_{2}$ and its metabolites were separated on a $0.5 \times 50 \mathrm{~mm}$ Saphire $110 \mathrm{C} 18(5 \mu \mathrm{m})$ capillary column eluted with a gradient of $0-5 \mathrm{~min} 10 \%$ mobile phase $B$ and 5-30 min 10-40\% mobile phase $B$ at a flow rate of $15 \mu \mathrm{l} / \mathrm{min}$, where mobile phase $A$ was $10 \mathrm{mM}$ triethylamine in water and mobile phase B was $65: 35$ (v/v) acetonitrile : methanol. Elution profiles (150-750 m/z) were monitored online by negative-ion mode ESI mass spectrometry. (a) EIC of $351.1 \mathrm{~m} / \mathrm{z}\left(\mathrm{PGD}_{2}\right.$ and $\left.15 \mathrm{k}-\mathrm{PGD}_{2}\right)$. The inset shows the averaged negative-ion mass spectra acquired during the elution of $\mathrm{PGD}_{2}\left(\mathrm{~m} / \mathrm{z} 351.1[\mathrm{M}-\mathrm{H}]^{-}, \mathrm{m} / \mathrm{z} 333.1[\mathrm{M}-\mathrm{H}-\right.$ $\left.\left.\mathrm{H}_{2} \mathrm{O}\right]^{-}, \mathrm{m} / z 315.1\left[\mathrm{M}-2 \mathrm{H}_{2} \mathrm{O}-\mathrm{H}\right]^{-}\right)$. (b) EIC of $333.0 \mathrm{~m} / z\left(\mathrm{PGJ}_{2}, \ddot{A}^{12} \mathrm{PGJ}_{2}, 15 \mathrm{~d}-\mathrm{PGD}_{2}\right)$. The dashed peak (15.8 min) in the 0-h trace originates from a $18 \mathrm{Da}$ loss from the single charged molecular ion ([M- $\mathrm{H}]^{-}, \mathrm{m} / z$ 351.1) of $\mathrm{PGD}_{2}$ during the ionization process, leading to a $\left[\mathrm{M}-\mathrm{H}_{2} \mathrm{O}-\mathrm{H}\right]^{-}$neutral loss fragment ion at $\mathrm{m} / \mathrm{z} 333.1$. (c) EIC of 315.1 $\mathrm{m} / \mathrm{z}\left(15 \mathrm{~d}-\mathrm{PGJ} \mathrm{J}_{2}\right)$. The negative-ion mass spectra of the $15 \mathrm{~d}-\mathrm{PGJ} \mathrm{J}_{2}$ peak are shown as an inset $\left(\mathrm{m} / \mathrm{z} 315.1[\mathrm{M}-\mathrm{H}]^{-}\right)$. In the medium, a compound with $\mathrm{m} / \mathrm{z} 315.2$ was detected, leading to additional peaks (labeled with an asterisk) in the $315.1 \mathrm{~m} / z$ EICs. All other signals in the EICs are due to a neutral loss (18 Da) from the molecular ions of $\mathrm{PGD}_{2}\left(\left[\mathrm{M}-2 \mathrm{H}_{2} \mathrm{O}-\mathrm{H}\right]^{-} \mathrm{m} / \mathrm{z} 315.1\right), \mathrm{PGJ}_{2}$ and $15 \mathrm{~d}-\mathrm{PGD}_{2}\left(\left[\mathrm{M}-\mathrm{H}_{2} \mathrm{O}-\mathrm{H}\right]^{-} \mathrm{m} / \mathrm{z} 315.1\right)$ occurring during the ionization process. Each extracted ion chromatogram was normalized to the highest peak. Incubation of $\mathrm{PGD}_{2}(5 \mu \mathrm{M})$ was carried out for 0,20 and $40 \mathrm{~h}$ at $37^{\circ} \mathrm{C}$ in culture medium

lysosomal structures (Figure 4g-j). Additionally, we observed a dilated flagellar pocket and the appearance of two or more flagellae in the same flagellar pocket (Figure 40 and p).

\section{Analysis of the mitochondrial membrane potential and the DNA content}

$\mathrm{PGD}_{2}$-induced cell death of $T$. brucei includes a set of different cellular changes such as loss of mitochondrial membrane potential $(\Psi \mathrm{m})$, DNA degradation and phosphatidylserine exposure in the outer leaflet. To investigate these parameters individually, exponentially growing cells were treated for $24 \mathrm{~h}$ with either $\mathrm{J}$ series or $\mathrm{D}$ series metabolites before they were sorted according to size and fluorescent label using a FACScalibur ${ }^{\mathbb{B}}$ cell sorter (BD Biosciences). Using propidium iodide staining as a control for necrosis, we could never detect a significant staining (data not shown). As shown in Figure 5a, treated cells were generally smaller in size than control cells.
In addition, cell death was associated with a loss of the $\Psi \mathrm{m}$, as reflected by a leftward shift of the histograms obtained using tetramethylrhodamine (TMRE) staining (Figure 5b). After $24 \mathrm{~h}, 24.5 \%$ of $P \mathrm{PJ}_{2}$-treated cells had a low $\Psi \mathrm{m}$, as compared with $6.1 \%$ of control cells. Cells treated with $\Delta^{12} P \mathrm{PJ}_{2}$ and $15 \mathrm{~d}-$ $\mathrm{PGJ}_{2}$ showed 18.3 and $12.8 \%$ $\Psi \mathrm{m}$ disruption, respectively. Treatment of cells with 17 phenyl- $\mathrm{PGD}_{2}$ depolarized the mitochondrial membrane, which is consistent with the results obtained after $\mathrm{PGD}_{2}$ treatment. ${ }^{23}$ Control experiments using valinomycin completely abolished the $\Psi \mathrm{m}$ (Figure $5 b$ ).

We also observed that cell death induced by $\mathrm{J}$ series metabolites was associated with a loss of DNA content. As shown in Figure $5 \mathrm{c}$, a significant percentage of the nuclei of treated cells had a low DNA content: $47.1 \%$ for $\mathrm{PGJ}_{2}$ and $14.5 \%$ for $\Delta^{12} P \mathrm{PJ}_{2}$-treated cells versus $3.9 \%$ for control cells. $\Delta^{12} \mathrm{PGJ} \mathrm{J}_{2}$ treatment increased the percentage of nuclei with Iow DNA content to $36.9 \%$ after $32 \mathrm{~h}$ (data not shown). Interestingly, $15 \mathrm{~d}-\mathrm{PGJ}_{2}$ was not able to induce DNA degradation, even after $32 \mathrm{~h}$ treatment with concentrations up to $5 \mu \mathrm{M}$. 

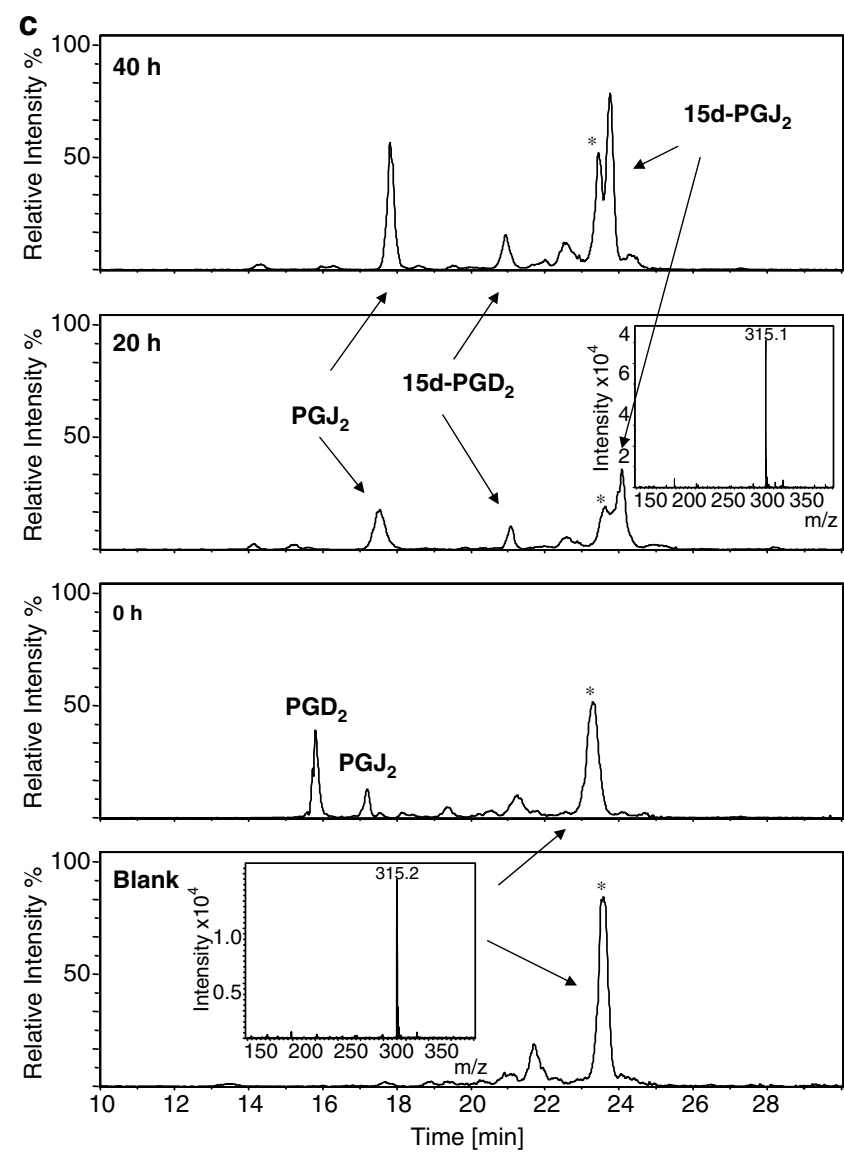

Figure 2 (Continued)

Table $1 \quad I_{50}$ values for the different prostaglandins

\begin{tabular}{llr}
\hline & Prostaglandin & IC $_{\mathbf{5 0}}(\boldsymbol{\mu} \mathrm{M})$ \\
\hline D series & $\mathrm{PGD}_{2}$ & $3.7 \pm 0.6$ \\
& 15 deoxy-PGD & $31.6 \pm 4.4$ \\
J series & $15 k e t o-\mathrm{PGD}_{2}$ & $104 \pm 8.7$ \\
& $\mathrm{PGJ}_{2}$ & $2.7 \pm 0.3$ \\
& $\Delta^{12} \mathrm{PGJ}_{2}$ & $0.7 \pm 0.4$ \\
& 15 deoxy-PGJ $_{2}$ & $3.5 \pm 0.3$ \\
& $\mathrm{PGF}_{2 \alpha}$ & $199 \pm 19$ \\
& 17 phenyl-PGD & $7.7 \pm 1.3$
\end{tabular}

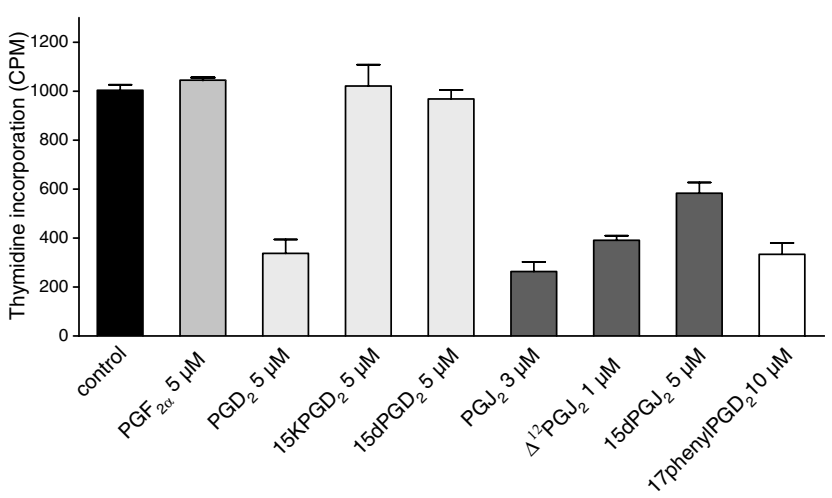

Figure $3 \quad\left[{ }^{3} \mathrm{H}\right]$ thymidine incorporation after $24 \mathrm{~h}$ treatment with the different metabolites. Control cells were treated with ethanol. The bars represent the mean and S.D. of three independent experiments
However, when this experiment was carried out with cells of the stationary phase, which had been shown to be more sensitive to the action of PGs than logarithmically growing cells, ${ }^{23}$ DNA degradation reached 16.2 versus $2.5 \%$ for control cells after only $4 \mathrm{~h}$ of incubation with $15 \mathrm{~d}-\mathrm{PGJ}_{2}$.

In addition, cell cycle analysis of treated cells clearly indicated an increase of cells in the G1 phase, which was paralleled by a decrease of cells remaining in the $\mathrm{G} 2$ and $S$ phases (Figure $5 \mathrm{~d}$ ). After a $32 \mathrm{~h}$ treatment, the level of cells in the G1 phase was about $20 \%$ increased as compared with control cells. The cell cycle arrest induced by $15 d-P G J_{2}$ was rather moderate, with only a $10 \%$ difference as compared with cells incubated under control conditions, which did not increase further with time.

\section{Detection of DNA disruption following $\mathrm{J}$ series PG treatment}

In another set of experiments, we examined the incorporation of deoxyuridinetriphosphate (dUTP) using terminal deoxynucleotidyl transferase-mediated dUTP-biotin nick end labeling (TUNEL) assay to investigate if $\mathrm{J}$ series metabolites are able to induce DNA degradation. This assay was performed using cells from the exponential growing phase after $24 \mathrm{~h}$ of incubation with the respective PGs. Figure 6 shows the incorporation of dUTP into nuclei of control and treated cells. Only samples that were treated with $P G J_{2}, \Delta^{12} P G J_{2}$, or 17 phenyl- $P G D_{2}$ showed a nuclear staining, which was not seen in control cell and scarcely observed in cells treated with $15 d-P G J_{2}$ (data not shown). Quantification was visually monitored by counting of 100 labeled and unlabeled cells each in three independent experiments. After $24 \mathrm{~h}, \mathrm{PGJ}_{2}$, $\Delta^{12} \mathrm{PGJ}_{2}$ - and 17phenyl-PGD ${ }_{2}$-treated cells showed 40,21 and $39 \%$ positive staining, respectively (Figure 6). These results are consistent with those obtained by fluorescenceactivated cell sorting (FACS) analysis.

\section{Detection of phosphatidylserine exposure after treatment with PGs of the $\mathrm{J}$ series}

One of the first phenotypic changes associated to PCD is the exposition of phosphatidylserine residues on the surface of the plasma membrane. ${ }^{31}$ In order to assay this parameter and, if observed, to confirm that it is an early event in T. brucei PCD that requires protein biosynthesis, we used cells from the stationary phase (i.e. stumpy cells) as they are more sensitive than dividing parasites.

As shown in Figure $7 \mathrm{a}$, J series metabolites were able to induce phosphatidylserine exposure after only a few hours of treatment. This phenotype was prevented by treatment with cycloheximide before the incubation with PGs (Figure 7b). Likewise, cycloheximide delayed the cell death. The results indicate that phosphatidylserine exposure and the subsequent cell death caused by the administered PGs are processes that depend on protein biosynthesis.

Taken together, all these results indicate that the $\mathrm{J}$ series metabolites, mainly $P \mathrm{PJ}_{2}$, are able to induce cell death more rapidly and at lower concentrations than their precursor $\mathrm{PGD}_{2}$. 


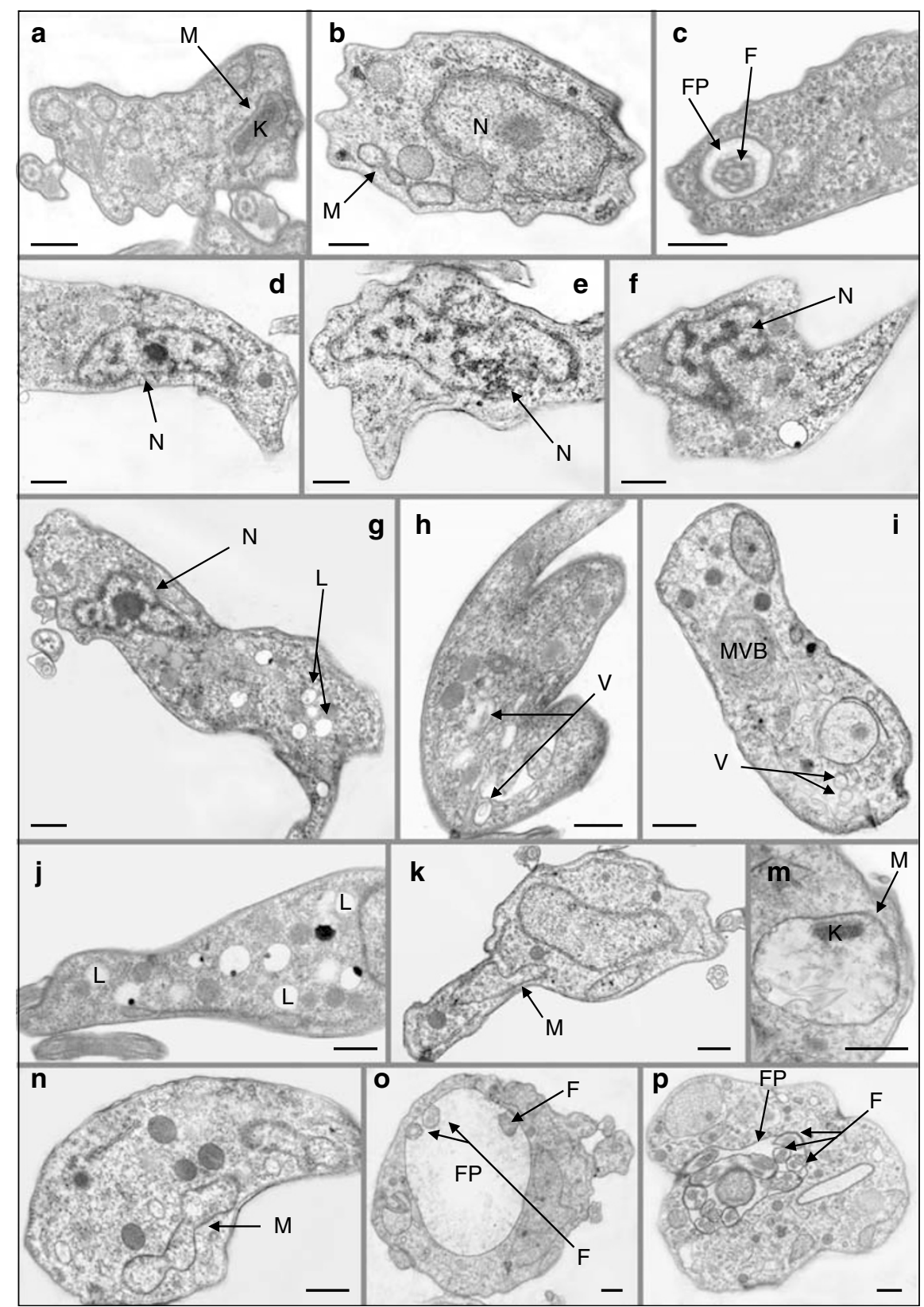

Figure 4 Transmission electron microscopy (TEM) of Epon-embedded cells. The most obvious alterations in J series metabolites-treated cells are as follows: (1) structures of condensed chromatin near the nuclear envelope (d-e); (2) dilated flagellar pockets and appearance of two or more flagellae in the same flagella pocket (o, p); (3) dilated mitochondria (k-n); and (4) an elevated amount of lysosomes ( $\mathbf{g}, \mathbf{j})$ as compared with control cells. Note the usual appearance of mitochondria, nucleus and flagella pocket in control cells (a, b and $\mathbf{c}$, respectively). Bars in TEM represent $0.5 \mu \mathrm{m}$ each. Abbreviations used: lysosome (L); nucleus (N); flagellum (F); flagella pocket (FP); mitochondrion (M)

\section{Measurement of reactive oxygen species after treatment with $\mathrm{PGD}_{2}$ and their active metabolites}

Previous studies have demonstrated that PGs are potential inducers of intracellular stress via production of reactive oxygen species (ROS). ${ }^{32,33}$ In order to investigate if this phenomenon is involved in the $P C D$ induced by $P G D_{2}$ metabolites in $T$. brucei, we used the sensitive probe $2^{\prime}, 7^{\prime}$ dichlorodihydrofluorescein diacetate (DCFH-DA). This nonfluorescent dye diffuses across cell membranes and is hydrolyzed to dichlorohydrofluorescein (DCFH) intracellularly. In the presence of ROS, DCFH is rapidly oxidized to highly fluorescent dichlorofluorescein. For this assay, we used cells from the stationary phase (after about $40 \mathrm{~h}$ ), again because they are more sensitive to the apoptosis-like effects of PGs than the slender form of parasites. ${ }^{23}$ As shown in Figure 8, treatment of the bloodstream forms of trypanosomes with $P G J_{2}$ for $2 \mathrm{~h}$ evoked an abrupt ROS generation. This effect was also induced by $\Delta^{12} P \mathrm{GJ}_{2}, 15 \mathrm{~d}-\mathrm{PGJ}_{2}$ and 17-phenyl$\mathrm{PGD}_{2}$, although after a much longer incubation time. 
a

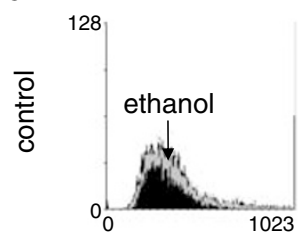

b
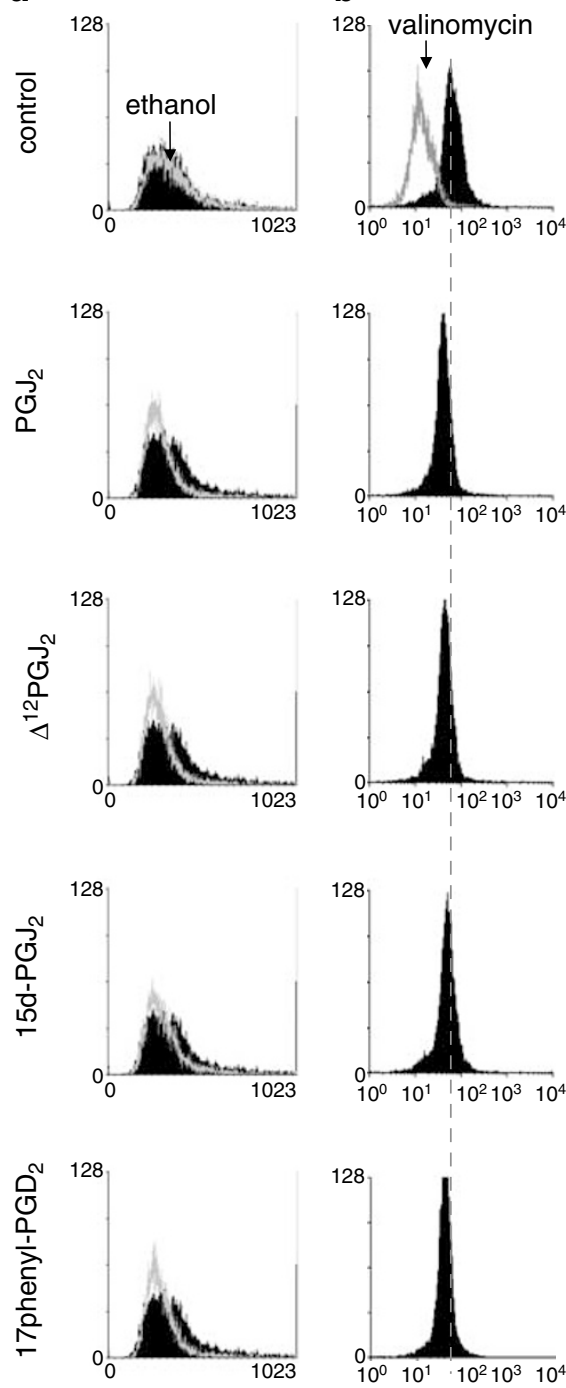

C
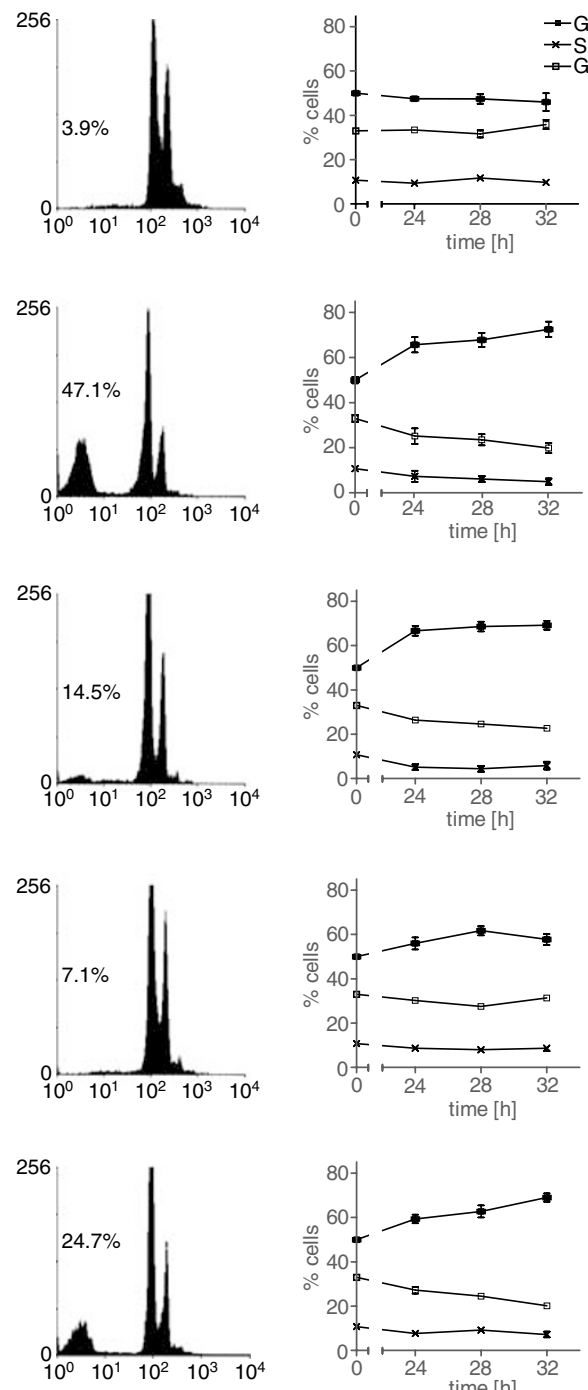

d
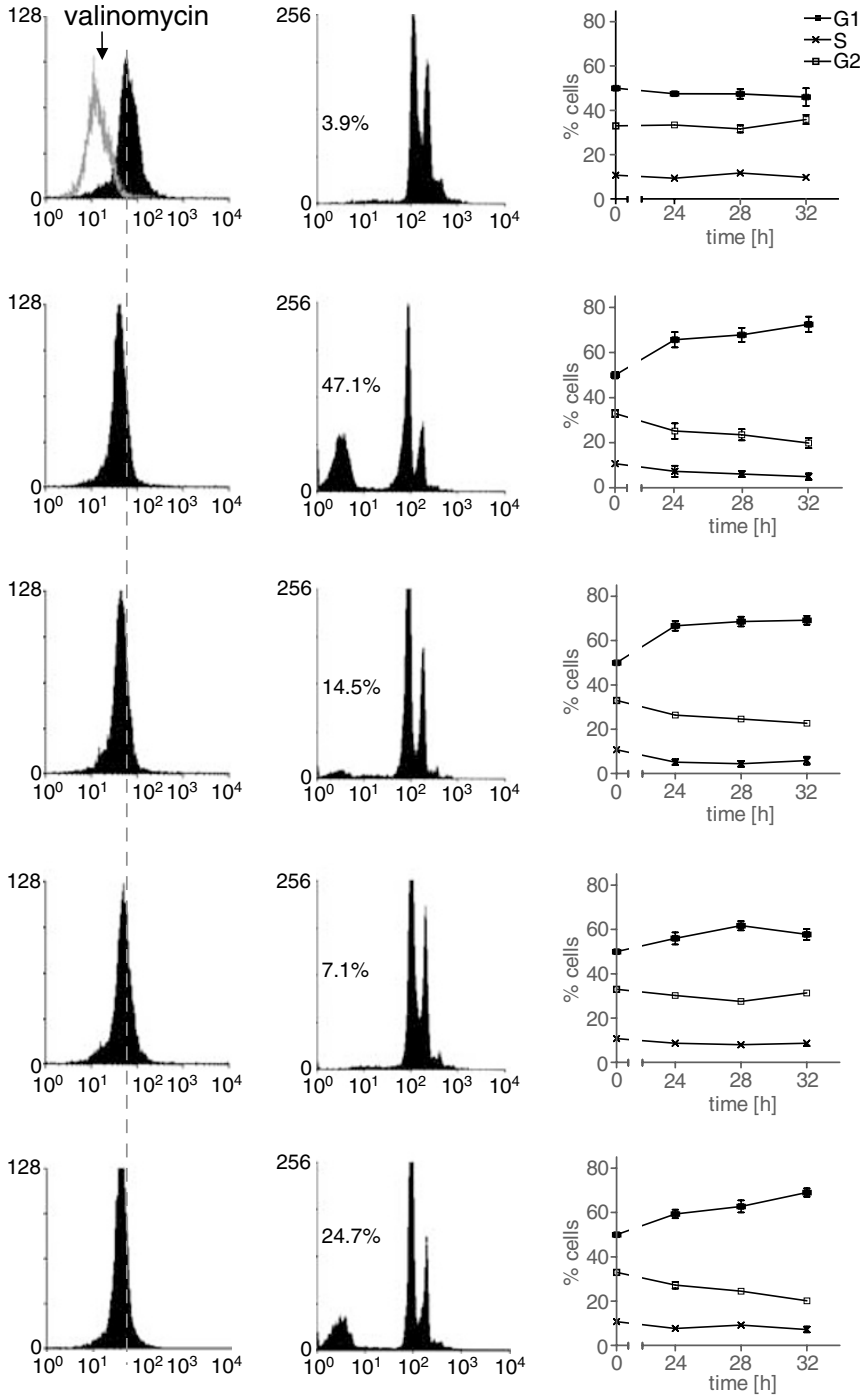

Figure 5 Propidium iodide or TMRE staining of bloodstream forms in FACS analysis. Cells were treated for $24 \mathrm{~h}$ with different metabolites $\left(\mathrm{PG} \mathrm{J}_{2} 3 \mu \mathrm{M}, \Delta^{12} \mathrm{PG} \mathrm{J}_{2}\right.$ $1.5 \mu \mathrm{M}, 15 \mathrm{~d}-\mathrm{PGJ}_{2} 5 \mu \mathrm{M}$ and 17 phenyl-PGD $\left.10 \mu \mathrm{M}\right)$ and prepared for analysis of DNA content and $\Psi \mathrm{m}$. From left to right, cell size (a), $\Psi \mathrm{m}(\mathbf{b})$, DNA content (c) and the phases of cell cycle (d) are shown. (a) The black histograms represent control cells and the gray line corresponds to cells treated with ethanol or metabolites. A positive control was performed with valinomycin for $\Psi \mathrm{m}$. Percentages of cells in G1, S and G2 phase at $0,24,28$ and $32 \mathrm{~h}$ were determined using the CellQuest ${ }^{\mathbb{R}}$ software

Furthermore, ROS production induced either by $\mathrm{PGD}_{2}$ or its metabolites was completely abolished by pretreatment with the thiol compounds NAC or glutathione. Likewise, NAC was also able to inhibit the PG effect on cellular growth, and occurrence of PCD phenotype markers such as morphological changes, phosphatidylserine exposure and DNA degradation (Figure 9), suggesting that the mechanism by which PGs mediate their effects involves alteration of the cellular redox status. Interestingly, untreated trypanosomes from the late stationary phase showed also an increased intracellular ROS level $(25.1 \pm 3.5 \%)$ as compared with NAC-treated parasites from the same phase $(7.9 \pm 1.0 \%)$. These parasites died more rapidly than those treated with NAC (data not shown).

On the other hand, ROS formation has been shown to require an upregulation of protein biosynthesis, in particular of enzymes involved in their formation. ${ }^{34,35}$ Interestingly, pretreatment of trypanosomes with cycloheximide led to a significant inhibition of ROS production, suggesting that protein synthesis is a prerequisite for PCD (Figure 8).

\section{Discussion}

In a previous study, we reported the capacity of $P G D_{2}$ to induce PCD in the bloodstream forms of trypanosomes, which appeared to be a caspase-independent apoptosis. ${ }^{23}$ However, the instability of this prostanoid in albumin-containing aqueous solutions and its subsequent conversion to different metabolites has been already demonstrated. ${ }^{25}$ In addition, it was reported earlier that growth inhibition induced in murine leukemia cells after exposition to $P G D_{2}$ was in fact due to an active metabolite, $\Delta^{12} P G J_{2}$, and that $P G D_{2}$ exerted no growth inhibition by itself. ${ }^{36}$ We thus analyzed the metabolic conversion of $\mathrm{PGD}_{2}$ under our experimental conditions in order to 


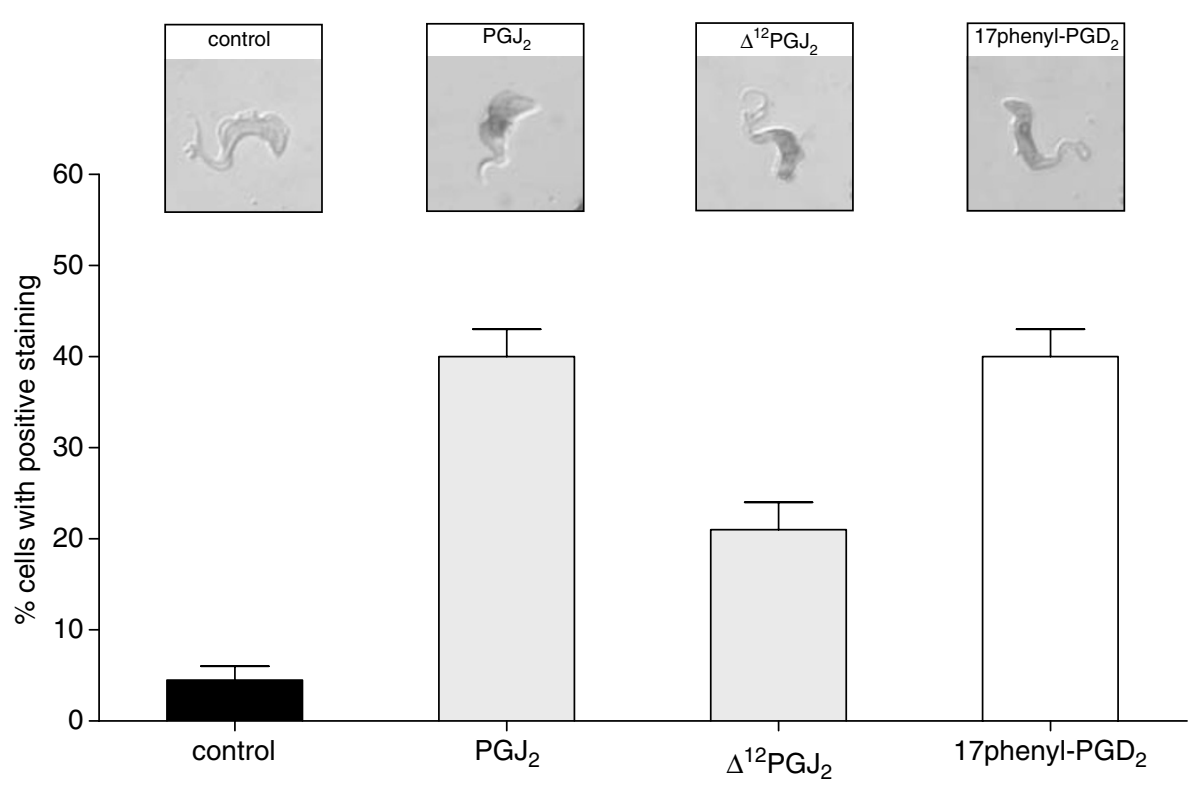

Figure 6 DNA double strand nicks staining using the TUNEL assay. Quantification was performed by counting 100 cells in three independent experiments
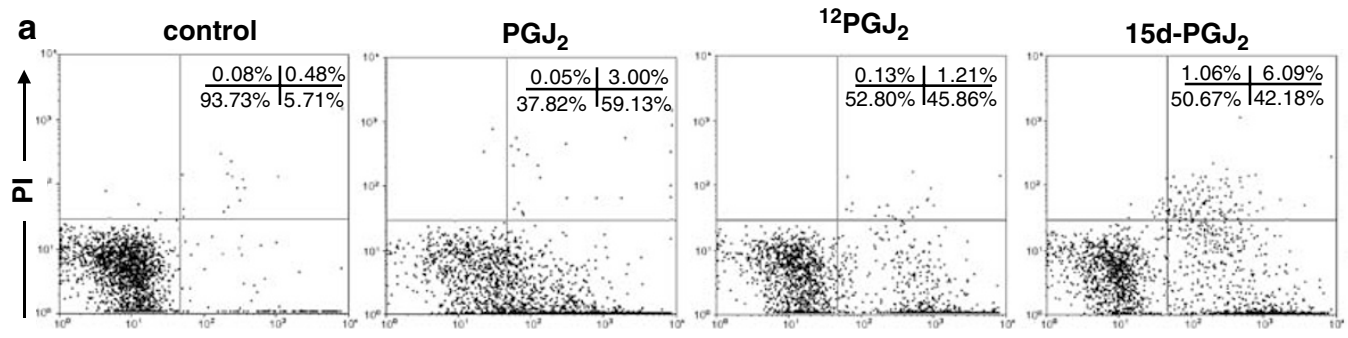

17phenyl-PGD 2

Annexin V
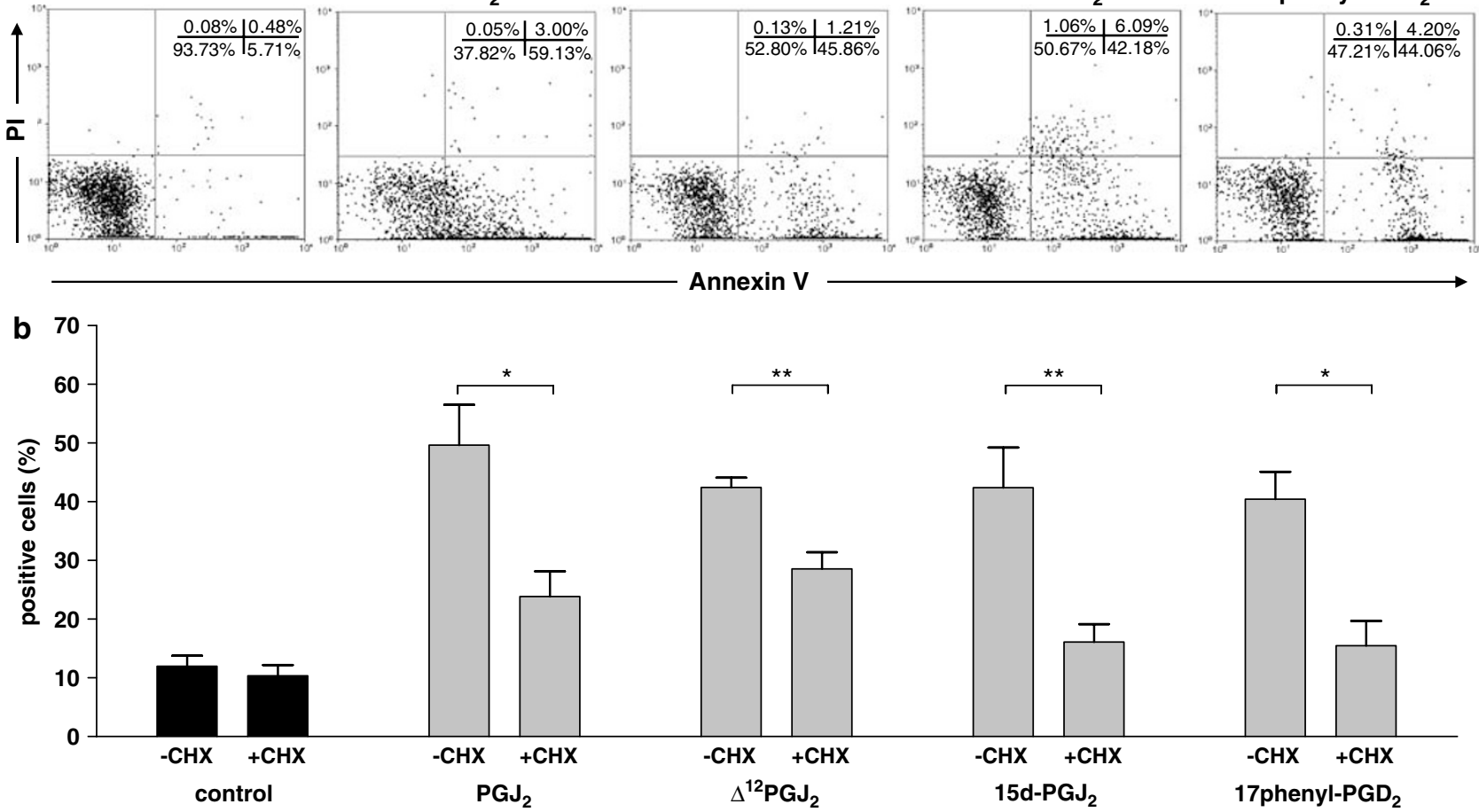

Figure 7 Determination of phosphatidylserine exposition. (a) Phosphatidylserine exposure measured by double staining with Annexin-V-Fluos and propidium iodide. Cells from the stationary phase were treated during $2 \mathrm{~h}\left(\mathrm{PGJ}_{2} 2 \mu \mathrm{M}\right), 4 \mathrm{~h}\left(\Delta^{12} \mathrm{PGJ}_{2} 1.5 \mu \mathrm{M}, 15 \mathrm{~d}-\mathrm{PGJ}_{2} 5 \mu \mathrm{M}\right)$ and $6 \mathrm{~h}\left(17 \mathrm{phenyl}-\mathrm{PGD} \mathrm{D}_{2} 10 \mu \mathrm{M}\right)$ with the indicated PGs. The dot plots represent the results of a typical experiment. (b) Phosphatidylserine exposure was inhibited by cycloheximide (CHX). The bars represent the mean and S.D. of three independent experiments. The asterisks indicate significant differences calculated by Student's $t$-test, using the GraphPad Software $\left({ }^{* *} P<0.01 ;{ }^{*} P<0.05\right)$

determine if the induced cell death was indeed due to the formation of more potent products. $\mathrm{PGD}_{2}$ metabolization was a quick event, as it was reduced to about $80 \%$ after $12 \mathrm{~h}$ of incubation (data not shown). Using LC-ESI/MS, we identified various metabolites of the $D$ and $J$ series. Addition of $D$ series metabolites had no effects on trypanosomes. The $\mathrm{IC}_{50}$ values for these metabolites were 10- to 30-fold higher than those for $\mathrm{PGD}_{2}$. In contrast, addition of $\mathrm{J}$ series metabolites led to a significant inhibition of cellular proliferation. The $\mathrm{IC}_{50}$ values for $P G J_{2}$ and $\Delta^{12} P G J_{2}$ were significantly lower than those for 


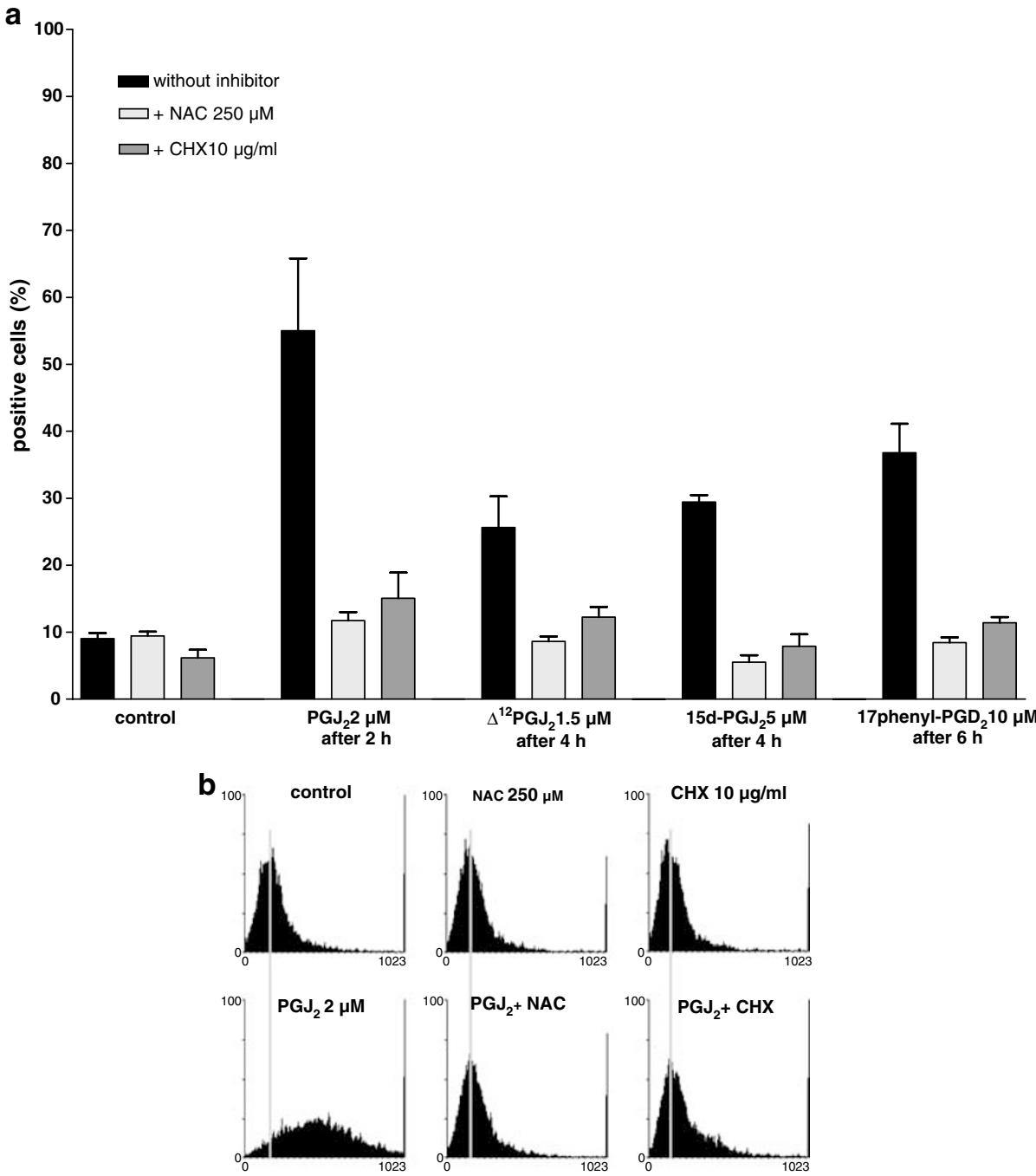

Figure 8 Measurement of ROS generation after PG treatment using DCFH-DA. Cells from the stationary phase were treated for $2 \mathrm{~h}\left(\mathrm{PG} \mathrm{J}_{2} 2 \mu \mathrm{M}\right), 4 \mathrm{~h}\left(\Delta^{12} \mathrm{PG} \mathrm{J}_{2}\right.$ $\left.1.5 \mu \mathrm{M}, 15 \mathrm{~d}-\mathrm{PGJ}_{2} 5 \mu \mathrm{M}\right)$ or $6 \mathrm{~h}\left(\mathrm{PGD}_{2} 7.5 \mu \mathrm{M}, 17\right.$ phenyl-PGD $\left.10 \mu \mathrm{M}\right)$ with the indicated PGs and then prepared to measure intracellular ROS. (a) Intracellular ROS values for control and PG-treated cells. Addition of $\mathrm{N}$-acetyl-L-cysteine (NAC) or cycloheximide (CHX) significantly attenuated the ROS production. (b) Representative FACS histograms showing the ROS-sensitive fluorescence of control and treated trypanosomes after $2 \mathrm{~h}$ incubation

$P G D_{2}$, whereas $15 d-P G J_{2}$ inhibited cell growth at concentrations similar to those of $\mathrm{PGD}_{2}$. Treatment with these metabolites led to cell cycle arrest in the G1 phase, as evidenced by FACS analysis and morphological changes, suggesting that this phenomenon is the principal effect exerted by $\mathrm{J}$ series metabolites on the slender form. The $P G$ concentrations used in the described experiments are in the low micromolar or nanomolar range and thus, comparable and often lower than those used in similar studies with different mammalian cell types. ${ }^{15,16,32}$ In addition, it is widely described in the literature that the effective $P G$ concentration is only a small fraction of the total, as they bind readily to albumin. ${ }^{37}$ At our conditions, at least $80 \%$ of $\mathrm{PGD}_{2}$ was sequestered owing to albumin binding. ${ }^{23}$ On assuming that this is also the case for the $\mathrm{J}$ metabolites, the effective PG concentrations have been in the low nanomolar range. On the other hand, the PGs are local mediators, and it has been reported that PG concentrations increase to the micromolar range during inflammation. ${ }^{14}$
Local events may play an important role in the parasite's life, because bloodstream forms shuttle between blood and extravascular tissue. Indeed, it has been demonstrated that differentiation from slender to stumpy form increased owing to local effects. ${ }^{38}$ Therefore, the actual PG concentrations may well be of physiological significance.

Similar to $\mathrm{PGD}_{2}$, J series metabolites induced characteristic features of PCD in trypanosomes. Using electron microscopy, FACS analysis and TUNEL test, we observed an increase of vacuolization in the cytoplasm, nuclear segmentation, chromatin condensation, DNA degradation and phosphatidylserine exposition. In addition, the recorded loss of $\Psi \mathrm{m}$ correlates with the microscopic observation of dilated mitochondria.

Using cells from the stationary phase, which represent stumpy-like cells ${ }^{39}$ and are more sensitive to PGs than the slender form of parasites, ${ }^{23}$ confirmed that phosphatidylserine exposure is an early event in T. brucei PCD. This phenotype 

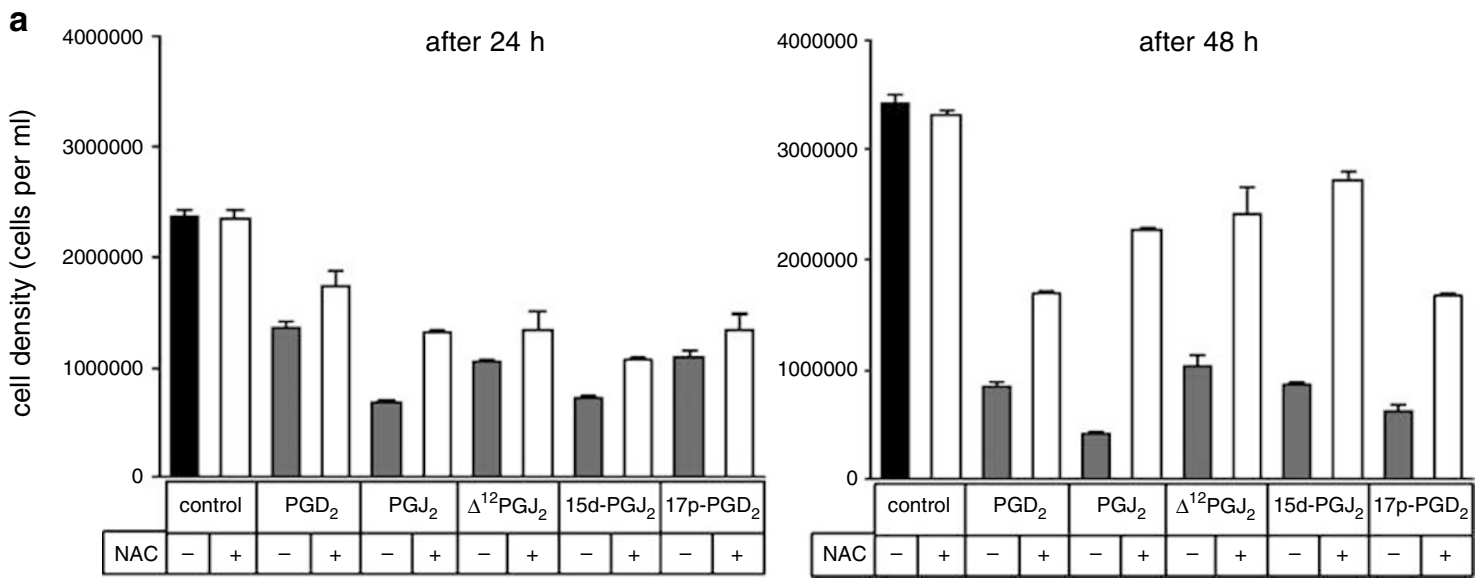

b

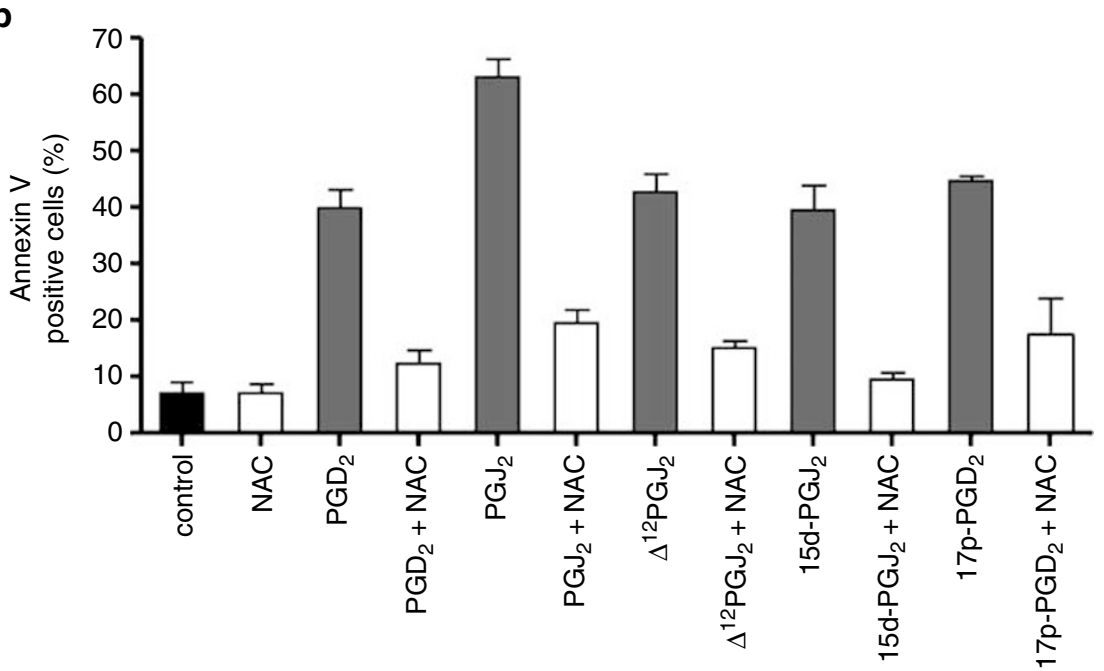

\section{d}

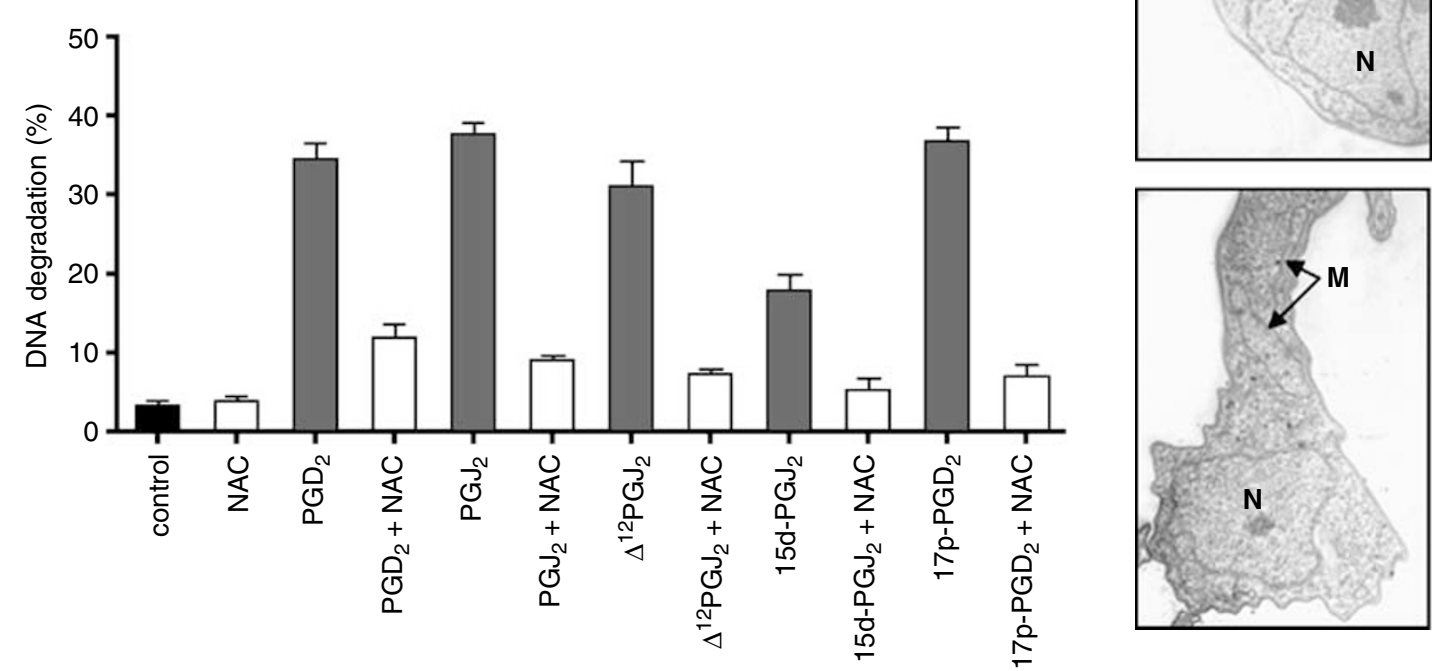

Figure 9 Inhibition of the cell death phenotype by incubation with NAC. Cells were treated with the indicated PGs in the presence or absence of NAC (250 $\mu \mathrm{M})$. (a) After 24 and $48 \mathrm{~h}$, cell density was determined using a hemocytometer. NAC protects the trypanosomes, as shown by the increase of the cell density in these cultures. Pretreatment of cells from stationary phase with NAC also prevented phosphatidylserine exposure (b) and DNA degradation (c) induced by PGs. (d) Morphology of trypanosomes treated with $\mathrm{PGJ}_{2}$ plus NAC. Abbreviations used: nucleus (N); flagellum (F); flagella pocket (FP); mitochondrion (M)

depends on protein biosynthesis, because short-time pretreatment with cycloheximide inhibited the phosphatidylserine exposure and significantly delayed PCD.
On the other hand, 17phenyl-PGD 2 , which was only slowly metabolized under our experimental conditions (data not shown), led to the same phenotype as $\mathrm{PGD}_{2}$, indicating that 
this latter compound is able to induce PCD itself. However, the concentration required to obtain the same effects was about two-fold higher than that of $P G D_{2}$. These results suggest that the induced phenotype is partially owing to the action of $P G D_{2}$, and that $\mathrm{J}$ series metabolites may be the more physiological inducers of PCD in the bloodstream form of $T$. brucei.

In general, PCD induced by $\mathrm{J}$ series metabolites was highly dependent on the growth phase. These PGs trigger cell death more rapidly and efficiently in the stationary than in the exponential growth phase. Similar results were found during $\mathrm{PGD}_{2}$ treatment or pretreatment with a membrane-permeable cAMP analog, which induced differentiation from slender to stumpy form, and enhanced the parasite's sensitivity for $\mathrm{PGD}_{2}{ }^{23}$ Therefore, our data indicate that these PGs primarily exert their effects on the stumpy form of parasites.

Despite the well-documented action of ROS as harmful molecules, they have also been shown to play an important role in signal transduction in innumerable physiological events. ${ }^{35,40-44}$ In addition, ROS have also been described to participate in the signal cascades associated to PCD. ${ }^{28,32,33,45-49}$ Likewise, PGs are potent inductors of oxidative stress in different cell types. This alteration of the redox state is known to be the basis of many of their biological effects and was recently discovered to be involved in the activation of $\mathrm{PCD} .{ }^{28,32,33} 15 \mathrm{~d}-\mathrm{PGJ}_{2}$ has been reported to cause apoptosis in human hepatic myofibroblasts and breast cancer cells via oxidative stress. ${ }^{28,33} \mathrm{PGD}_{2}$ and $P G J_{2}$ as well as their metabolites (but not $\mathrm{PGE}_{2}$ or $\mathrm{PGF}_{2 \alpha}$ ) induce apoptosis in human leukemia cells through ROS production and caspase 3 activation. ${ }^{49}$ Therefore, we investigated if PCD in $T$. brucei is also induced by PGs via ROS generation. FACS analyses using DCFH-DA showed that all three $\mathrm{J}$ metabolites assayed stimulated ROS production. $P \mathrm{PJ}_{2}$ was the most potent ROS inductor, followed by $\Delta^{12} P \mathrm{GJ}_{2}$ and $15 \mathrm{~d}-\mathrm{PGJ}_{2}$. Interestingly, the potency to induce ROS was always closely related with the capacity to cause $P C D$. In addition, $\mathrm{PGD}_{2}$ and its analog 17phenyl-PGD 2 also generated high ROS levels. Interestingly, ROS appearance was always the first event observed after treatment of the parasites with prostanoids. As shown earlier, different biological effects induced by PGs via ROS production (even PCD in other cells) were prevented by treatment with antioxidants. ${ }^{28,32}$ In trypanosomes, pretreatment with two ROS scavengers, NAC or glutathione, completely inhibited the ROS production and occurrence of the other PCD phenotype markers induced by PGs and led to a significant reduction of cell death. Taken together, we propose that ROS are implicated as intermediates in the PCD signaling pathway induced by $\mathrm{J}$ series $\mathrm{PG}$. These results are consistent with the data published by Ridgley et al., ${ }^{50}$ who stated that the increase of ROS led to PCD-like phenomena in procyclic trypanosomes. In addition, Fang and Beattie ${ }^{51}$ showed that the trypanosome alternative oxidase (TAO) decreases the mitochondrial ROS production, and recently Tsuda et al. $^{52}$ demonstrated that TAO overexpression prevents PCD-like phenomena in the bloodstream form of T. b. rhodesiense.

The sensibility of PCD to protein synthesis inhibitors is an important feature, which clearly links this phenomenon to gene expression. Similarly, other compounds involved in the ROS signal pathway could require an upregulation of protein biosynthesis. This was the rationale to examine if ROS generation by PGs depends on this process. Parasites pretreated with cycloheximide and exposed to the different prostanoids showed no elevated ROS levels or phosphatidylserine exposition and survived a much longer time. These results are consistent with those reported for different neuronal cell types, in which apoptosis is triggered by ROS; their formation was totally or partially blocked by transcription and translation inhibitors. ${ }^{53,54}$ We thus conclude that PG-induced ROS formation is a prerequisite for PCD in T. brucei.

Oxidative stress is considered to be an important condition to promote cell death in response to a variety of signals. Our results provide evidences for the existence of an active process of PCD in T. brucei, which involves de novo protein synthesis and oxidative stress.

PCD in single-cell organisms, from bacteria to unicellular eucaryotes, is well documented. ${ }^{55-59}$ To date, the physiological role of PCD in single-cell organisms has not clearly been defined. However, PCD functions similar to those known for metazoa have been suggested for unicellular organisms too, ${ }^{59,60}$ because protozoa behave as a population, that is, as a complex community with many cell-cell interactions, which in many ways resemble metazoa. ${ }^{59,60}$ Evidence of this crosstalk among trypanosomes is well documented for the differentiation process from the proliferative slender to the non-dividing stumpy form. Differentiation depends on cell density, where local effects like cell-to-cell communication play an important role. ${ }^{38}$ Thus, differentiation has been suggested as an autoregulatory process, stopping significantly the cellular proliferation. ${ }^{38}$ Although it is known that wave parasitemia can be reproduced in vitro, ${ }^{6}$ mechanisms of the parasite to regulate the stumpy form density have not been described so far. We propose that $\mathrm{PGD}_{2}$ secretion by trypanosomes and production of their $\mathrm{J}$ series metabolites play a key role as regulators of cell density within their host by $P C D$ induction in the stumpy form of parasites via cell cycle regulation. In this sense, an elevation of the PG levels could arrest or diminish the parasitemia by elimination of the nondividing form, which represents a transitory stage unable to return to the proliferative slender form. This mechanism of regulation would not compromise the parasites population for two reasons: (1) it would not cause PCD in the proliferative slender form, guaranteeing a persisting parasitemia, and (2) it would be an autolimited process, as PGs involved in PCD are secreted mainly by the stumpy form.

\section{Materials and Methods}

\section{Reagents}

PGs were purchased from the Caiman Chemical Co. (Ann Arbor, MI, USA). Triethylamine and solvents used were obtained from Merck (Darmstadt, Germany). Methyl-[ $\left[{ }^{3} \mathrm{H}\right]$ thymidine was obtained from Hartmann Analytic (Braunschweig, Germany). The TUNEL kit and AnnexinV-Fluos were purchased from Roche Diagnostics GmbH (Mannheim, Germany). NAC and glutathione were obtained from Sigma-Aldrich (Deisenhofen, Germany). DCFH-DA was purchased from Molecular Probes (Karlsruhe, Germany). 
PGs were reconstituted in ethanol and diluted to the respective concentrations using culture medium. The respective ethanol concentration was always applied to control cells as well.

\section{Separation and identification of $\mathrm{PGD}_{2}$ metabolites by LC-ESI/MS}

In order to analyze the $P G D_{2}$ metabolism, this $P G$ was incubated in medium at $37^{\circ} \mathrm{C}$. After different time points $(0,20,40 \mathrm{~h}), \mathrm{PGs}$ in the medium were extracted with $4 \mathrm{ml}$ of ethylacetate $(1: 2, \mathrm{v} / \mathrm{v})$ three times. The upper organic phases were pooled and evaporated to dryness under a stream of nitrogen at room temperature. All extraction procedures were performed under conditions of minimal light. Before the LC-ESI/MS analysis, samples (resuspended in $50 \mu$ of acetonitrile : methanol $(65: 35$, $\mathrm{v} / \mathrm{v})$ ) were diluted $1: 10(\mathrm{v} / \mathrm{v})$ with $10 \mathrm{mM}$ triethylamine and $10 \mu \mathrm{l}$ was directly injected onto the column. LC was performed on a $0.5 \times 50 \mathrm{~mm}$ Saphire $110 \mathrm{C} 18(5 \mu \mathrm{m})$ capillary column (Grom, Herrenberg, Germany) attached to an HP1100 capillary HPLC system (Agilent Technologies, Waldbronn, Germany). Mobile phase A was $10 \mathrm{mM}$ triethylamine in water and mobile phase B was 65:35 (v/v) acetonitrile:methanol. Samples were separated by a gradient program: $0-5$ min $10 \%$ mobile phase $B$ and 5-30 $\mathrm{min} 10-40 \%$ mobile phase $B$ at a flow rate of $15 \mu \mathrm{l} / \mathrm{min}$. The outlet of the column was directly interfaced with the electrospray ionization source of an Esquire 3000plus ion trap mass spectrometer (Bruker-Daltonics, Bremen, Germany). The mass spectrometer was operated in the negativeion mode. Dry gas (6 $1 / \mathrm{min})$ temperature was set to $275^{\circ} \mathrm{C}$, nebulizer was set to $20.0 \mathrm{psi}$ and the electrospray voltage was set to $+3000 \mathrm{~V}$. Maximal accumulation time was set to $200 \mathrm{~ms}$. Loading of the trap was controlled by the instrument (ICC 15000). Mass spectra were acquired from 150 to $750 \mathrm{~m} / \mathrm{z}$, using four averages. All signals were detected as monoisotopic masses.

\section{Cell culture}

The monomorphic strain T. brucei MITat 1.2 (VSG-variant 221) was taken from frozen stabilates, seeded at a cell density of $2 \times 10^{5}$ cells $/ \mathrm{ml}$ and grown at $37^{\circ} \mathrm{C}$ and $5 \% \mathrm{CO}_{2}$ for about $16 \mathrm{~h}$, until a cell density of $8 \times 10^{5} \mathrm{cells} / \mathrm{ml}$ was reached. ${ }^{6,39}$ These precultures were then adjusted to $2 \times 10^{5}$ trypanosomes $/ \mathrm{ml}$ with fresh medium and incubated again in a $\mathrm{CO}_{2}$ incubator with $\mathrm{PGs}$ at the given concentrations. Experiments were performed with exponentially growing parasites (slender form) to evaluate cellular proliferation, cell cycle and partially PCD. Parasites from the stationary phase, equivalent to stumpy forms, were used to evaluate PCD. For experiments using cycloheximide (an inhibitor of protein synthesis), cells were grown until they reached the stationary phase, preincubated for $1 \mathrm{~h}$ with this inhibitor and treated with the respective PG. All experiments were performed at least in triplicate.

\section{Cytotoxicity assay}

The $I C_{50}$ values were determined according to Bodley et al. ${ }^{61}$ Exponentially growing parasites were diluted to $2 \times 10^{5} \mathrm{celll} / \mathrm{ml}$, placed in 96-well microtiter plates and grown in the absence or presence of different $P G$ concentrations. Plates were incubated for $24 \mathrm{~h}$ at $37^{\circ} \mathrm{C}$ in a $\mathrm{CO}_{2}$ incubator. Cell growth was stopped by the addition of lysis buffer containing $p$-nitrophenyl phosphate $(20 \mathrm{mg} / \mathrm{ml}$ in $1 \mathrm{M}$ sodium acetate, $\mathrm{pH}$ 5.5 , containing $1 \%$ Triton X-100). Likewise, addition of this buffer started the acid phosphatase reaction, which was measured at $405 \mathrm{~nm}$ after $6 \mathrm{~h}$ incubation by using an ELISA reader (MRX II, Dynex Technologies, Middlesex, England).

\section{Proliferation assay}

The cellular proliferation was determined by measuring thymidine incorporation. Cultures were adjusted to $2 \times 10^{5}$ cells $/ \mathrm{ml}$ and seeded into 96-well microtiter plates. After $24 \mathrm{~h}$ incubation at $37^{\circ} \mathrm{C}$ and $5 \% \mathrm{CO}_{2}$, trypanosomes were pulsed for $4 \mathrm{~h}$ with methyl- $\left[{ }^{3} \mathrm{H}\right]$ thymidine $(1 \mu \mathrm{Ci} /$ well), harvested immediately and washed twice in PBS. Cells were lysed in 5\% SDS and counted in a liquid scintillation counter.

\section{Transmission electron microscopy}

Control or treated cells were harvested after $24 \mathrm{~h}$ incubation with PGs and prepared for TEM. The cells were fixed in $2 \%$ glutaraldehyde in $0.2 \mathrm{M}$ sodium cacodylate buffer containing $0.12 \mathrm{M}$ sucrose for $1 \mathrm{~h}$ at $4^{\circ} \mathrm{C}$. After washing and storage overnight in sodium cacodylate buffer, cells were post-fixed in osmium tetroxide $(1.5 \%, \mathrm{w} / \mathrm{v})$ and stained in $0.5 \%$ uranyl acetate. $^{62}$ Dehydration in ethanol, clearing in propylene oxide and embedding in Agar 100 (equivalent to Epon 812) were performed according to standard procedures. ${ }^{63}$ Sections were stained in $5 \%(\mathrm{w} / \mathrm{v})$ uranyl acetate and $0.4 \%(\mathrm{w} / \mathrm{v})$ lead citrate.

\section{TUNEL assay}

We used the in situ cell death detection kit obtained from Roche (Mannheim, Germany) in order to detect DNA double-strand ruptures. The assay procedure was performed as previously described. ${ }^{55}$ Briefly, trypanosomes were fixed in $4 \%$ paraformaldehyde and $0.2 \%$ glutaraldehyde in phosphate buffer for $1 \mathrm{~h}$ before they were placed on a slide for staining. The percentage of cells showing a clearly visible nucleus staining was determined in treated and untreated cells by counting three times 100 cells each.

\section{FACS analysis}

Mitochondrial membrane potential: This parameter was measured after incubation of PG-treated and untreated trypanosomes with $25 \mathrm{nM}$ TMRE for $30 \mathrm{~min}$ at $37^{\circ} \mathrm{C}$. Fluorescence analysis was performed in a FACSCalibur ${ }^{\circledR}$ apparatus (Becton Dickinson \& Co., NJ, USA). The ionophore valinomycin (100 nM) was used as a control for a complete depolarization of the inner mitochondrial membrane.

DNA content. The assay was performed as previously described. ${ }^{23}$ Briefly, following a 30 min permeabilization of trypanosomes in $10 \mathrm{mM}$ phosphate buffer containing $6 \mu \mathrm{M}$ digitonin, nuclei were stained with a propidium iodide solution $(10 \mu \mathrm{g} / \mathrm{ml}$ final concentration in $10 \mathrm{mM}$ phosphate buffer) and kept on ice until measurement in the cell sorter.

Necrosis: In order to analyze disruption of the plasma membrane after PG treatment, nuclei were stained with propidium iodide $(5 \mu \mathrm{g} / \mathrm{ml})$ in the absence of a cell permeant and analyzed by flow cytometry.

Phosphatidylserine exposure: Exposed phosphatidylserine was detected on the outer membrane of cells using Annexin-V-Fluos ${ }^{\mathbb{R}}$ (Roche, Mannheim, Germany) according to the manufacturer's protocol. Fluorescence was measured using FACS analysis as described before.

Reactive oxygen species: DCFH-DA was employed to measure intracellular oxidative stress. ${ }^{34}$ Control and treated cells were incubated with $10 \mu \mathrm{M} \mathrm{DCFH-DA}$ for $1 \mathrm{~h}$ at $37^{\circ} \mathrm{C}$. The cellular fluorescence intensity was measured using a flow cytometer as described above. 


\section{Acknowledgements}

We are grateful for the valuable technical help from Alexandra Thor. This work was funded by the Deutsche Forschungsgemeinschaft (DFG); KF and $\mathrm{NU}$ are recipients of personal grants from DAAD (Germany) and $\mathrm{CDCH}$ (Venezuela), respectively.

\section{References}

1. Mahan SM and Black SJ (1989) Differentiation, multiplication and control of bloodstream form Trypanosoma (Duttonella) vivax in mice. J. Protozool. 36 : 424-428

2. Vickerman K (1985) Developmental cycles and biology of pathogenic trypanosomes. Br. Med. Bull. 41: 105-114

3. Borst P, Rudenko G, Taylor MC, Blundell PA, Van Leeuwen F, Bitter W, Cross $M$ and McCulloch R (1996) Antigenic variation in trypanosomes. Arch. Med. Res. 27: 379-388

4. Sternberg MJ and Mabbott NA (1996) Nitric oxide-mediated suppression of T cell responses during Trypanosoma brucei infection: soluble trypanosome products and interferon-gamma are synergistic inducers of nitric oxide synthase. Eur. J. Immunol. 26: 539-543

5. Schleifer KW and Mansfield JM (1993) Suppressor macrophages in African trypanosomiasis inhibit $\mathrm{T}$ cell proliferative responses by nitric oxide and prostaglandins. J. Immunol. 151: 5492-5503

6. Hesse F, Selzer PM, Muhlstadt K and Duszenko M (1995) A novel cultivation technique for long-term maintenance of bloodstream form trypanosomes in vitro. Mol. Biochem. Parasitol. 70: 157-166

7. Tyler KM, Higgs PG, Matthews KR and Gull K (2001) Limitation of Trypanosoma brucei parasitaemia results from density-dependent parasite differentiation and parasite killing by the host immune response. Proc. R. Soc. London B 268: 2235-2243

8. Pentreath VW, Rees K, Owolabi OA, Philip KA and Doua F (1990) The somnogenic T lymphocyte suppressor prostaglandin D2 is selectively elevated in cerebrospinal fluid of advanced sleeping sickness patients. Trans. R. Soc. Trop. Med. Hyg. 84: 795-799

9. Smith SK (1989) Prostaglandins and growth factors in the endometrium. Baillieres Clin. Obstet. Gynaecol. 3: 249-270

10. Smith SK and Ahmed A (1992) Eicosanoid synthesis and Helicobacter pylori associated gastritis: increase in leukotriene $\mathrm{C} 4$ generation associated with H. pylori colonization. Prostaglandins 44: 457-470

11. Samuelsson B (1979) Prostaglandins, thromboxanes, and leukotrienes: formation and biological roles. Harvey Lect. 75: 1-40

12. Dubois R, Lapillonne A, Laine X, Claris O, Bouvier R, Chappuis JP and Tsujii M (1998) Cyclooxygenase regulates angiogenesis induced by colon cancer cells. Pediatr. Surg. Int. 13: 346-349

13. Hayaishi $O$ (2000) Molecular mechanisms of sleep-wake regulation: a role of prostaglandin D2. Philos. Trans. R. Soc. London B 355: 275-280

14. Nencioni A, Lauber K, Grunebach F, Van Parijs L, Denzlinger C, Wesselborg S and Brossart P (2003) Cyclopentenone prostaglandins induce lymphocyte apoptosis by activating the mitochondrial apoptosis pathway independent of external death receptor signaling. J. Immunol. 171: 5148-5156

15. Shibata T, Kondo M, Osawa T, Shibata N, Kobayashi M and Uchida K (2002) 15-Deoxy-delta 12,14-prostaglandin J2. A prostaglandin D2 metabolite generated during inflammatory processes. J. Biol. Chem. 277: 10459-10466

16. Ward C, Dransfield I, Murray J, Farrow SN, Haslett C and Rossi AG (2002) Prostaglandin D2 and its metabolites induce caspase-dependent granulocyte apoptosis that is mediated via inhibition of I kappa $B$ alpha degradation using a peroxisome proliferator-activated receptor-gamma-independent mechanism. J. Immunol. 168: 6232-6243

17. Alam M (1986) Ionophore A23187 stimulates Entamoeba histolytica to release prostaglandin F2 alpha. Prostaglandins Leukotr. Med. 22: 259-264

18. Kubata BK, Eguchi N, Urade Y, Yamashita K, Mitamura T, Tai K, Hayaishi $O$ and Horii T (1998) Plasmodium falciparum produces prostaglandins that are pyrogenic, somnogenic, and immunosuppressive substances in humans. J. Exp. Med. 188: 1197-1202

19. Belley A and Chadee K (2000) Production of prostaglandin E(2) by Entamoeba histolytica via a novel cyclooxygenase. Arch. Med. Res. 31: 74-75
20. Kubata BK, Duszenko M, Kabututu Z, Rawer M, Szallies A, Fujimori K, Inui T, Nozaki T, Yamashita K, Horii T, Urade Y and Hayaishi O (2000) Identification of a novel prostaglandin $\mathrm{f}(2 \mathrm{alpha})$ synthase in Trypanosoma brucei. J. Exp. Med. 192: $1327-1338$

21. Fusco AC, Salafsky B and Delbrook K (1986) Schistosoma mansoni: production of cercarial eicosanoids as correlates of penetration and transformation. J. Parasitol. 72: 397-404

22. Prusch RD, Goette SM and Haberman P (1989) Prostaglandins may play a signal-coupling role during phagocytosis in Amoeba proteus. Cell Tissue Res. 255: 553-557

23. Figarella K, Rawer M, Uzcategui NL, Kubata BK, Lauber K, Madeo F, Wesselborg S and Duszenko M (2005) Prostaglandin D2 induces programmed cell death in Trypanosoma brucei bloodstream form. Cell Death Differ. 12: 335-346

24. Kubata BK, Duszenko M, Kabututu Z, Rawer M, Szallies A, Inui T, Urade $Y$ and Hayaishi $O$ (2002) Enzymatic formation of prostaglandin D2, E2, and F2a in the parasitic protozoan Trypanosoma brucei. Int. Congress Ser. 1233: 461-466

25. Fitzpatrick FA and Wynalda MA (1983) Albumin-catalyzed metabolism of prostaglandin D2. Identification of products formed in vitro. J. Biol. Chem. 258: $11713-11718$

26. Fukushima M (1992) Biological activities and mechanisms of action of PGJ2 and related compounds: an update. Prostaglandins Leukotr. Essent. Fatty Acids 47: 1-12

27. Padilla J, Kaur K and Phipps RP (2000) Effects of 15-deoxy-delta 12,14-PGJ2 on B lineage cells. Ann. NY Acad. Sci. 905: 322-325

28. Li L, Tao J, Davaille J, Feral C, Mallat A, Rieusset J, Vidal H and Lotersztajn S (2001) 15-Deoxy-delta 12,14-prostaglandin j2 induces apoptosis of human hepatic myofibroblasts. A pathway involving oxidative stress independently of peroxisome-proliferator-activated receptors. J. Biol. Chem. 276: 38152-38158

29. Kikawa $\mathrm{Y}$, Narumiya S, Fukushima M, Wakatsuka $\mathrm{H}$ and Hayaishi $\mathrm{O}(1984)$ 9-Deoxy-delta 9, delta 12-13,14 dihydroprostaglandin D2, a metabolite of prostaglandin D2 formed in human plasma. Proc. Natl. Acad. Sci. USA 81: 1317-1321

30. Haberl C, Hultner L, Flugel A, Falk M, Geuenich S, Wilmanns W and Denzlinger C (1998) Release of prostaglandin D2 by murine mast cells: importance of metabolite formation for antiproliferative activity. Mediators Inflamm. 7: 79-84

31. Bratton DL, Fadok VA, Richter DA, Kailey JM, Guthrie LA and Henson PM (1997) Appearance of phosphatidylserine on apoptotic cells requires calciummediated nonspecific flip-flop and is enhanced by loss of the aminophospholipid translocase. J. Biol. Chem. 272: 26159-26165

32. Kondo M, Oya-Ito T, Kumagai T, Osawa T and Uchida K (2001) Cyclopentenone prostaglandins as potential inducers of intracellular oxidative stress. J. Biol. Chem. 276: 12076-12083

33. Pignatelli M, Sanchez-Rodriguez J, Santos A and Perez-Castillo A (2005) 15-Deoxy-Delta-12,14-prostaglandin J2 induces programmed cell death of breast cancer cells by a pleiotropic mechanism. Carcinogenesis 26: 81-92

34. Herrera B, Murillo MM, Alvarez-Barrientos A, Beltran J, Fernandez $M$ and Fabregat I (2004) Source of early reactive oxygen species in the apoptosis induced by transforming growth factor-beta in fetal rat hepatocytes. Free Radic. Biol. Med. 36: 16-26

35. Thannickal VJ and Fanburg BL (2000) Reactive oxygen species in cell signaling. Am. J. Physiol. Lung Cell. Mol. Physiol. 279: 1005-1028

36. Narumiya S and Fukushima M (1985) Delta 12-prostaglandin J2, an ultimate metabolite of prostaglandin D2 exerting cell growth inhibition. Biochem. Biophys. Res. Commun. 127: 739-745

37. Raz A (1972) Interaction of prostaglandins with blood plasma proteins. Comparative binding of prostaglandins A2, F2 and E2 to human plasma proteins. Biochem. J. 130: 631-636

38. Reuner B, Vassella E, Yutzy B and Boshart M (1997) Cell density triggers slender to stumpy differentiation of Trypanosoma brucei bloodstream forms in culture. Mol. Biochem. Parasitol. 90: 269-280

39. Hamm B, Schindler A, Mecke D and Duszenko M (1990) Differentiation of Trypanosoma brucei bloodstream trypomastigotes from long slender to short stumpy-like forms in axenic culture. Mol. Biochem. Parasitol. 40: 13-22

40. White AA, Crawford KM, Patt CS and Lad PJ (1976) Activation of soluble guanylate cyclase from rat lung by incubation or by hydrogen peroxide. J. Biol. Chem. 251: 7304-7312 
41. Mittal CK and Murad F (1977) Activation of guanylate cyclase by superoxide dismutase and hydroxyl radical: a physiological regulator of guanosine $3^{\prime}, 5^{\prime}$-monophosphate formation. Proc. Natl. Acad. Sci. USA 74: 4360-4364

42. Roth $S$ and Droege W (1987) Regulation of T cell activation and T cell growth factor (TCGF) production by hydrogen peroxide. Cell Immunol. 108: 417-424

43. Schreck R, Rieber P and Baeuerle PA (1991) Reactive oxygen intermediates as apparently widely used messengers in the activation of the NF- $\kappa$ B transcription factor and HIV-1. EMBO J. 10: 2247-2258

44. Droege W (2001) Free radicals in the physiological control of cell function. Physiol. Rev. 82: 47-95

45. Chaudhri G, Hunt NH, Clark JA and Ceredig R (1988) Antioxidants inhibit proliferation and cell surface expression of receptors for interleukin-2 and transferrin in T-lymphocytes stimulated with phorbol myristate acetate and ionomycin. Cell Immunol. 115: 204-213

46. Nakamura K, Hori T, Sato N, Sugie K, Kawakami T and Yodoi J (1993) Redox regulation of a src family protein tyrosine kinase p56lck in T cells. Oncogene 8: 3133-3139

47. Russo T, Zambrano N, Esposito F, Ammendola R, Cimino F, Fiscella M, Jackman J, O'Connor PM, Anderson CW and Appella E (1995) A p53independent pathway for activation of WAF1/CIP1 expression following oxidative stress. J. Biol. Chem. 270: 29386-29391

48. Esposito F, Cuccovillo F, Vanoni M, Cimino F, Anderson CW, Appella E and Russo T (1997) Redox-mediated regulation of p21waf/cip1 expression involves a post-transcriptional mechanism and activation of the mitogen-activated protein kinase pathway. Eur. J. Biochem. 245: 730-737

49. Chen YC, Shen SC and Tsai SH (2005) Prostaglandin D2 and J2 induce apoptosis in human leukemia cells via activation of caspase 3 cascade and production of reactive oxygen species. Biochem. Biophys. Acta 1743: 291-304

50. Ridgley EL, Xiong ZH and Ruben L (1999) Reactive oxygen species activate a $\mathrm{Ca}^{2+}$-dependent cell death pathway in the unicellular organism Trypanosoma brucei brucei. Biochem. J. 340: 33-40

51. Fang $\mathrm{J}$ and Beattie DS (2003) Alternative oxidase present in procyclic Trypanosoma brucei may act to lower the mitochondrial production of superoxide. Arch. Biochem. Biophys. 414: 294-302
52. Tsuda A, Witola WH, Ohashi K and Onuma M (2005) Expression of alternative oxidase inhibits programmed cell death-like phenomenon in bloodstream form of Trypanosoma brucei rhodesiense. Parasitol. Int. 54: 243-251

53. Schulz JB, Henshaw DR, Siwek D, Jenkins BG, Ferrante RJ, Cipolloni PB, Kowall NW, Rosen BR and Beal MF (1995) Involvement of free radicals in excitotoxicity in vivo. J. Neurochem. 64: 2239-2247

54. Tan S, Sagara Y, Liu Y, Maher P and Schubert D (1998) The regulation of reactive oxygen species production during programmed cell death. J. Cell Biol. 141: 1423-1432

55. Madeo F, Frohlich E and Frohlich KU (1997) A yeast mutant showing diagnostic markers of early and late apoptosis. J. Cell Biol. 139: 729-734

56. Arnoult D, Tatischeff I, Staquier J, Girard M, Sureau F, Tissier JP, Grodet A, Dellinger M, Traincard F, Kahn A, Ameisen JC and Petit PX (2001) On the evolutionary conservation of the cell death pathway: mitochondrial release of an apoptosis-inducing factor during Dictyostelium discoideum cell death. Mol. Cell. Biol. 12: 3016-3030

57. Arnoult D, Akarid K, Grodet A, Petit PX, Estaquier J and Ameisen JC (2002) On the evolution of programmed cell death: apoptosis of the unicellular eukaryote Leishmania major involves cysteine proteinase activation and mitochondrion permeabilisation. Cell Death Differ. 9: 65-81

58. Piacenza L, Peluffo $G$ and Radi R (2001) -Arginine-dependent suppression of apoptosis in Trypanosoma cruzi: contribution of the nitric oxide and polyamine pathways. Proc. Natl. Acad. Sci. USA 98: 7301-7306

59. Lewis K (2000) Programmed death in bacteria. Microbiol. Mol. Biol. Rev. 64 503-514

60. Tan K and Nasirudeen A (2005) Protozoan programmed cell death - insights from Blastocystis deathstyles. Trends Parasitol. 21: 547-550

61. Bodley AL, McGarry MW and Shapiro TA (1995) Drug cytotoxicity assay for African trypanosomes and Leishmania species. J. Infect. Dis. 172: 1157-1159

62. Hirsch JG and Fedorko ME (1968) Ultrastructure of human leukocytes after simultaneous fixation with glutaraldehyde and osmium tetroxide and 'postfixation' in uranyl acetate. J. Cell Biol. 38: 615-627

63. Glauert AM, Butterworth AE, Sturrock RF and Houba V (1978) The mechansim of antibody-dependent, eosinophil-mediated damage to schistosomula of Schistosoma mansoni in vitro: a study by phase-contrast and electron microscopy. J. Cell Sci. 34: 173-192 